Provided for non-commercial research and education use. Not for reproduction, distribution or commercial use.

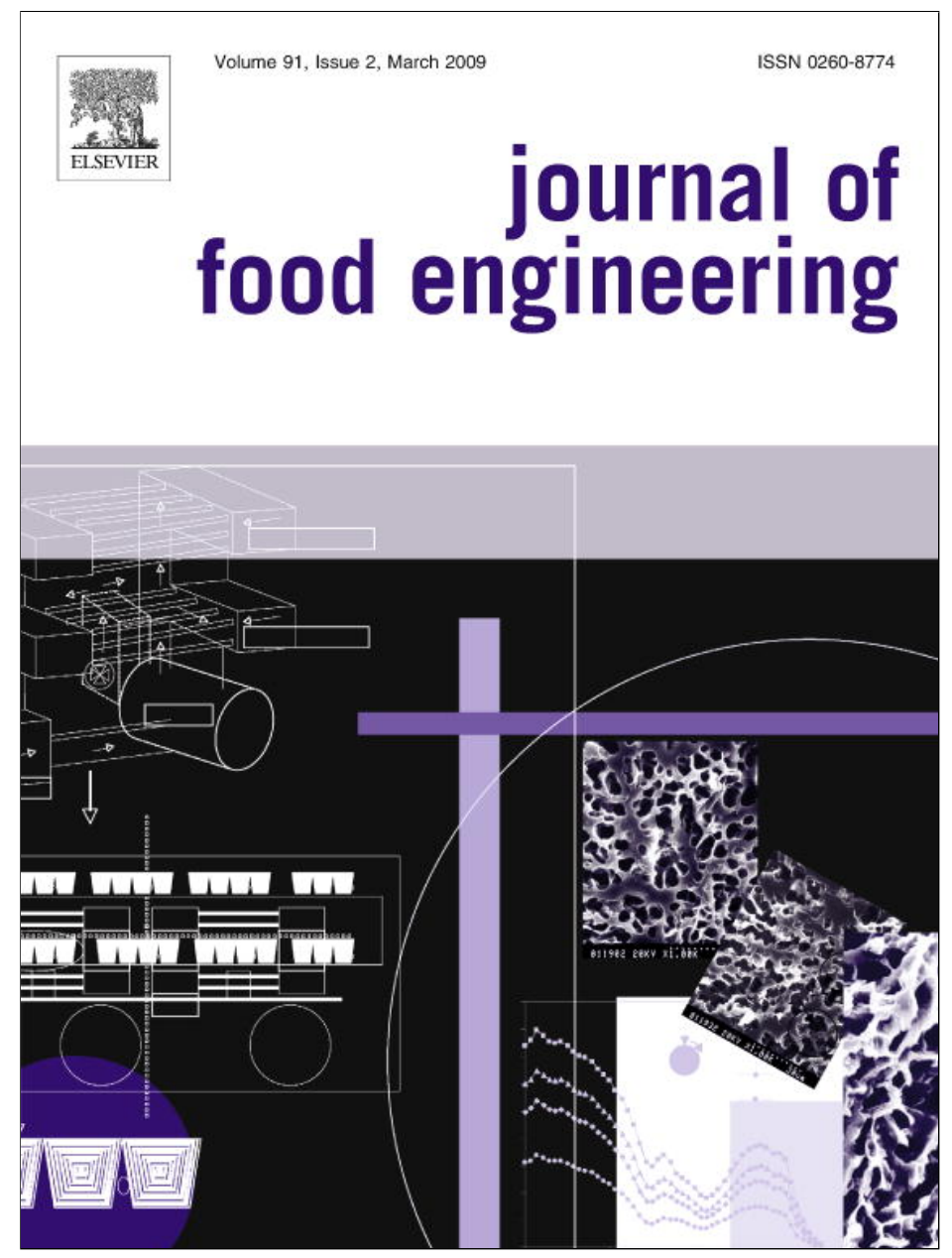

This article appeared in a journal published by Elsevier. The attached copy is furnished to the author for internal non-commercial research and education use, including for instruction at the authors institution and sharing with colleagues.

Other uses, including reproduction and distribution, or selling or licensing copies, or posting to personal, institutional or third party websites are prohibited.

In most cases authors are permitted to post their version of the article (e.g. in Word or Tex form) to their personal website or institutional repository. Authors requiring further information regarding Elsevier's archiving and manuscript policies are encouraged to visit:

http://www.elsevier.com/copyright 


\title{
Optimization of the humidification of cold stores by pressurized water atomizers based on a multiscale CFD model
}

\author{
M.A. Delele ${ }^{\mathrm{a}, *}$, A. Schenk ${ }^{\mathrm{b}}$, E. Tijskens ${ }^{\mathrm{a}}$, H. Ramon ${ }^{\mathrm{a}}$, B.M Nicolaï ${ }^{\mathrm{a}, \mathrm{b}}$, P. Verboven ${ }^{\mathrm{a}}$ \\ ${ }^{a}$ BIOSYST-MeBioS, Katholieke Universiteit Leuven, Willem de Croylaan 42, 3001 Leuven, Belgium \\ ${ }^{\mathrm{b}}$ Flanders Centre of Postharvest Technology, Willem de Croylaan 42, 3001 Leuven, Belgium
}

\section{A R T I C L E I N F O}

\section{Article history:}

Received 9 June 2008

Received in revised form 26 August 2008

Accepted 27 August 2008

Available online 6 September 2008

\section{Keywords:}

CFD

Cold storage

Humidification

Lagrangian model

Multiphase flow

Porous media

Fruit

\begin{abstract}
A B S T R A C T
Humidification during long-term cooled storage of fruits is being introduced into practice to prevent excessive moisture loss and quality degradation. High pressure fogging is one of the few systems that can be used in ultra low oxygen (ULO) storage rooms. For system design and optimization, a CFD based multiscale model was used. At the smallest scale, the flow through stacked products in boxes was predicted using a direct model that combined discrete element (DE)-CFD modelling. At larger scale, a loaded cool room model that predicts the storage room air velocity, temperature and humidity distributions and fate of the water droplets was developed. The loaded product was considered as a porous medium, where the anisotropic loss coefficients were determined from a combined DE-CFD simulation. A Lagrangian particle tracking multiphase flow model was used. An interval humidification of $1 \mathrm{~min}$ on and $15 \mathrm{~min}$ off with a water pressure of 80 bar $\left(3.59 \mathrm{~L} \mathrm{~h}^{-1}\right)$ for a ULO storage room at $-1{ }^{\circ} \mathrm{C}$ on average gave a relative humidity of $96.3 \%$. The amount of sprayed water deposited on the stack and room surfaces depend on the application pressure and nozzle position and direction. Good agreement was found between measured and predicted results.
\end{abstract}

(c) 2008 Elsevier Ltd. All rights reserved.

\section{Introduction}

The relative humidity $(\mathrm{RH})$ of storage rooms affects the quality of the stored products. Numerous previous studies reported a significant effect of RH on weight loss and firmness (Henriod, 2006; Hertog et al., 2004; Paull, 1999; Tu et al., 2000). The most important factors that affect the weight loss are the rate of respiration and the water vapour pressure difference between the surrounding air and the product surface. A low optimum storage temperature combined with a high $\mathrm{RH}$ of the surrounding air can reduce the weight loss. However, due to the condensation and freezing of water vapour on the cooling coils, maintaining the required high $\mathrm{RH}$ at subzero storage conditions is very difficult. The temperature difference between the cooler surface and the room air is the most important factor that controls the rate of condensation/freezing of water vapour on the cooling coils (Paull, 1999). To maintain the required high $\mathrm{RH}$, humidifying the cooling air using steam or atomized water droplets are the commonly used methods. However, an excessive RH level may encourage microbial spoilage and thus it is necessary to maintaining the RH at an acceptable level (Tassou and Xiang, 1998). Most of the previous studies discussed the advantages of humidification on decreasing the saleable weight

\footnotetext{
* Corresponding author. Tel.: +32 16322376; fax: +32 16322955

E-mail address: mulugetaadmasu.delele@biw.kuleuven.be (M.A. Delele).
}

loss and maintaining the product quality during storage. But it is hard to find any studies on the optimal operation and design of such humidification systems for sub-zero storage conditions which are commonly used for storing products such as pear.

Since it affects the storage room temperature during the time of injection, steam humidifier is not a good alternative. Cold water atomizing humidifier can avoid this increase of the storage room temperature, but due to the low evaporation rate of the water droplets at sub-zero optimum storage temperature (for instance, $-1{ }^{\circ} \mathrm{C}$ for conference pears or $-2{ }^{\circ} \mathrm{C}$ for chicory root) maintaining high $\mathrm{RH}(>95 \% \mathrm{RH})$ with minimum deposition of the droplets on the product surface is very challenging. There are four types of atomizers that are commonly used for such humidification purpose: high pressure, ultrasonic, air-assisted and rotary atomizes. However, for ULO storage at sub-zero temperature the high pressure system is the viable option. Due to the low operating temperature and low ejection velocity of the droplets from ultrasonic atomizer (Rajan and Pandit, 2001), the clogging of the ejector due to the freezing of the droplets on the surface makes its operation for such storage condition very difficult. In case of the air-assisted nozzles, the high velocity atmospheric air that is used for the atomization disturbs the air composition of the ULO room. Rotary atomizers are quite complex (Bayvel and Orzechowski, 1993). Experimentally, the suitability of the pressurized water atomizers for humidification of storage rooms at $-1{ }^{\circ} \mathrm{C}$ was investigated successfully (Delele et al., 2007a). 


\begin{tabular}{|c|c|c|c|}
\hline \multicolumn{4}{|c|}{ Nomenclature } \\
\hline$A_{\mathrm{c}}$ & heat transfer area of the cooler, $\mathrm{m}^{2}$ & $S_{\mathrm{e}}$ & energy source term, $\mathrm{J} \mathrm{m}^{-3} \mathrm{~s}^{-1}$ \\
\hline$A_{\text {spec }}$ & specific area, $\mathrm{m}^{2} \mathrm{~m}^{-3}$ & $S_{\mathrm{m}}$ & mass source term, $\mathrm{kg} \mathrm{m}^{-3} \mathrm{~s}^{-1}$ \\
\hline$a_{\mathrm{w}}$ & water activity & $S_{u}$ & momentum source term, $\mathrm{kg} \mathrm{m}^{-2} \mathrm{~s}^{-2}$ \\
\hline$C_{\mathrm{d}}$ & drag coefficient & $t$ & time, $s$ \\
\hline$C_{p}$ & specific heat, $\mathrm{J} \mathrm{kg}^{-1}{ }^{\circ} \mathrm{C}^{-1}$ & $T$ & temperature, ${ }^{\circ} \mathrm{C}$ \\
\hline$d$ & droplet diameter, m & $T_{\mathrm{o}}$ & reference temperature, ${ }^{\circ} \mathrm{C}$ \\
\hline $\begin{array}{l}D_{\mathrm{p}} \\
\mathrm{Co}_{\mathrm{ys}}\end{array}$ & $\begin{array}{l}\text { product equivalent diameter, } \mathrm{m} \\
\text { vapour concentration on the droplet surface, } \mathrm{kmol} \mathrm{m}^{-3}\end{array}$ & $u_{i}, u_{\mathrm{j}}$ & $\begin{array}{l}\text { mean velocity components in } X, Y \text {, and Z-directions, } \\
\mathrm{m} \mathrm{s}^{-1}\end{array}$ \\
\hline $\mathrm{CO}_{\mathrm{v}, \infty}$ & vapour concentration in the bulk air, $\mathrm{kmol} \mathrm{m}^{-3}$ & $u_{i}^{\prime}, u_{i}^{\prime}$ & fluctuating velocity components, $\mathrm{m} \mathrm{s}^{-1}$ \\
\hline & molecular diffusion coefficient, $\mathrm{m}^{2} \mathrm{~s}^{-1}$ & $U_{\mathrm{c}}$ & calculated velocity, $\mathrm{m} \mathrm{s}^{-1}$ \\
\hline$D_{\mathrm{t}}$ & turbulent diffusion coefficient, $\mathrm{m}^{2} \mathrm{~s}^{-1}$ & $U_{\mathrm{m}}$ & measured velocity, $\mathrm{m} \mathrm{s}^{-1}$ \\
\hline$E$ & relative error, \% & $u_{\mathrm{s}}$ & superficial velocity, $\mathrm{m} \mathrm{s}^{-1}$ \\
\hline$g$ & gravitational acceleration, $\mathrm{m} \mathrm{s}^{-2}$ & $V_{\text {cell }}$ & cell volume, $\mathrm{m}^{3}$ \\
\hline$h$ & static enthalpy, $\mathrm{J} \mathrm{kg}^{-1}$ & $V_{\mathrm{H}_{2} \mathrm{O}}$ & molar volume of water, $18 \times 10^{-6} \mathrm{~m}^{3} \mathrm{~mol}^{-1}$ \\
\hline$h^{\prime}$ & fluctuating static enthalpy, $\mathrm{J} \mathrm{kg}^{-1}$ & $v_{i}$ & velocity, $\mathrm{m} \mathrm{s}^{-1}$ \\
\hline$h_{\mathrm{b}}$ & bulk product mass transfer coefficient, $\mathrm{kg} \mathrm{m}^{-2} \mathrm{~s}^{-1} \mathrm{~Pa}^{-1}$ & $x_{i}, x_{j}$ & Cartesian coordinates, $\mathrm{m}$ \\
\hline$h_{\mathrm{h}}$ & heat transfer coefficient, $\mathrm{W} \mathrm{\textrm {m } ^ { - 2 } \mathrm { C } ^ { - 1 }}$ & $X_{\mathrm{v}}$ & moisture content, $\mathrm{kg} \mathrm{kg}^{-1}$ \\
\hline$h_{\mathrm{m}}$ & mass transfer coefficient, $\mathrm{m} \mathrm{s}^{-1}$ & $Y_{\mathrm{v}}$ & vapour mass fraction \\
\hline$h_{\mathrm{oh}}$ & air film heat transfer coefficient, $\mathrm{W} \mathrm{m} \mathrm{m}^{-2} \mathrm{C}^{-1}$ & $Y_{\mathrm{v}}^{\prime}$ & fluctuating vapour mass fraction \\
\hline$h_{\mathrm{om}}$ & air film mass transfer coefficient, $\mathrm{kg} \mathrm{m}^{-2} \mathrm{~s}^{-1} \mathrm{~Pa}^{-1}$ & $\beta$ & Forchheimer drag coefficient, $\mathrm{m}^{-1}$ \\
\hline$h_{\mathrm{s}}$ & skin mass transfer coefficient, $\mathrm{kg} \mathrm{m}^{-2} \mathrm{~s}^{-1} \mathrm{~Pa}^{-1}$ & $\delta_{i j}$ & kronecker delta \\
\hline$k$ & turbulent kinetic energy, $\mathrm{m}^{2} \mathrm{~s}^{-2}$ & $\mu$ & molecular thermal conductivity, $\mathrm{W} \mathrm{m}^{-1}{ }^{\circ} \mathrm{C}^{-1}$ \\
\hline K & Darcy permeability, $\mathrm{m}^{2}$ & $\mu_{\text {eff }}$ & effective thermal conductivity of porous \\
\hline L & latent heat of condensation vaporization, $\mathrm{J} \mathrm{kg}^{-1}$ & & $\mathrm{~W} \mathrm{~m}^{-1}{ }^{\circ} \mathrm{C}^{-1}$ \\
\hline Le & Lewis number & $\lambda_{\mathrm{t}}$ & turbulent thermal conductivity, $\mathrm{W} \mathrm{m}^{-1}{ }^{\circ} \mathrm{C}^{-1}$ \\
\hline$m_{\mathrm{c}}$ & $\begin{array}{l}\text { moisture condensation evaporation rate at the cooler, } \\
\operatorname{kg~s}^{-1}\end{array}$ & $\mu$ & $\begin{array}{l}\text { dynamic viscosity, } \mathrm{kg} \mathrm{m}^{-1} \mathrm{~s}^{-1} \\
\text { turbulent viscosity } \mathrm{kg} \mathrm{m}^{-1} \mathrm{~s}^{-1}\end{array}$ \\
\hline$m_{\mathrm{d}}$ & mass of discrete droplet, $\mathrm{kg}$ & $\begin{array}{l}\mu_{\mathrm{t}} \\
\rho\end{array}$ & density, $\mathrm{kg} \mathrm{m}^{-3}$ \\
\hline $\begin{array}{l}m_{\mathrm{lp}} \\
M_{\mathrm{wy}}\end{array}$ & $\begin{array}{l}\text { product moisture loss, } \mathrm{kg} \mathrm{m}^{-3} \mathrm{~s}^{-1} \\
\text { molar mass of water vapour, } \mathrm{kg} \mathrm{kmol}^{-1}\end{array}$ & $\rho_{\text {vsat }}$ & $\begin{array}{l}\text { saturated vapour density, } \mathrm{kg} \mathrm{m}^{-3} \\
\text { porosity }\end{array}$ \\
\hline$n_{\mathrm{d}}$ & number of droplets in the cell & $\varphi$ & shape factor \\
\hline $\mathrm{Nu}$ & Nusselt number & & \\
\hline$p$ & pressure, $\mathrm{Pa}$ & Subscript & \\
\hline $\operatorname{Pr}_{\mathrm{t}}$ & turbulent Prandtl number & a & continuous air phase \\
\hline$P_{\mathrm{vp}}$ & vapour pressure on the product surface, $\mathrm{Pa}$ & c & cooler surface/interface between the cooler surface and \\
\hline$P_{\text {va }}$ & vapour pressure on the surrounding air, Pa & & cooling air \\
\hline$R$ & universal gas constant, $8.314 \mathrm{~J} \mathrm{~mol}^{-1} \mathrm{~K}^{-1}$ & $\mathrm{~d}$ & discrete droplet phase \\
\hline Re & particle Reynolds number & $\mathrm{p}$ & product \\
\hline$S c_{t}$ & turbulent Schmidt number & $i, j$ & Cartesian coordinate index \\
\hline
\end{tabular}

The use of experimental methods to set the optimum operating parameters that give such a high relative humidity without causing excessive water deposit on the product is very difficult. The use of CFD modelling is an alternative to the expensive and tedious experiments. A number of studies to model the air flow pattern and temperature distribution in cold storage rooms demonstrate the appropriateness of the method (Chourasia and Goswami, 2007; Hoang et al., 2000, 2003; Nahor et al., 2005; Tassou and Xiang, 1998; Xu and Burfoot, 1999). The humidification system is usually not modelled and for calculating the pressure loss coefficients for a flow through stacked products, these previous studies commonly used the Ergun (1952) correlation that does not consider any effect of the confining and vented box walls often encountered in fruit storage. For a flow through loaded vented strawberry package, Ferrua and Singh (2008) observed a nonhomogeneous and complex flow distribution; and stressed the need for geometrical and mathematical models that are capable of generating the geometry and predicting the flow through the package and product. The humidification system was modelled using a particle tracking approach (Delele et al., 2007b; Gouesbet and Berlemont, 1999).

In this paper, we present and validate a complete CFD model that predicts the storage room air velocity, temperature and humidity distributions and fate of the water droplets that were sprayed from humidifying nozzles. In this study the loss coefficients were determined using an explicit combined DE-CFD simulation that takes into account product geometrical properties, box design and the randomness of the product stacking (Delele et al., 2008).

\section{Materials and methods}

\subsection{Humidification system and cold storage room}

The study was conducted in a storage room with a secondary glycol cooling system $4.25 \mathrm{~m}$ in length, $2.8 \mathrm{~m}$ in width and $3.6 \mathrm{~m}$ in height (Fig. 1). The cooling unit was located at the back of the room. For the recirculation of the cooling air in the room two axial flow fans with a diameter of $40 \mathrm{~cm}$ and a capacity of $2140 \mathrm{~m}^{3} \mathrm{~h}^{-1}$ each were used. The humidification system (Becrou C.V.B.A, Brussels, Belgium) had a capacity up to 100 bar water pressure, and was equipped with an automatic controller that controls the on/off cycle. One humidifying nozzle (Delavan Inc., USA) was positioned in front of the cooler exit. The control system of the room was equipped with Pt100 and RH meters (Siemens Building Technologies Inc., Illinois, USA) with an accuracy of $\pm 0.5{ }^{\circ} \mathrm{C}$ and $\pm 5 \%$, for 


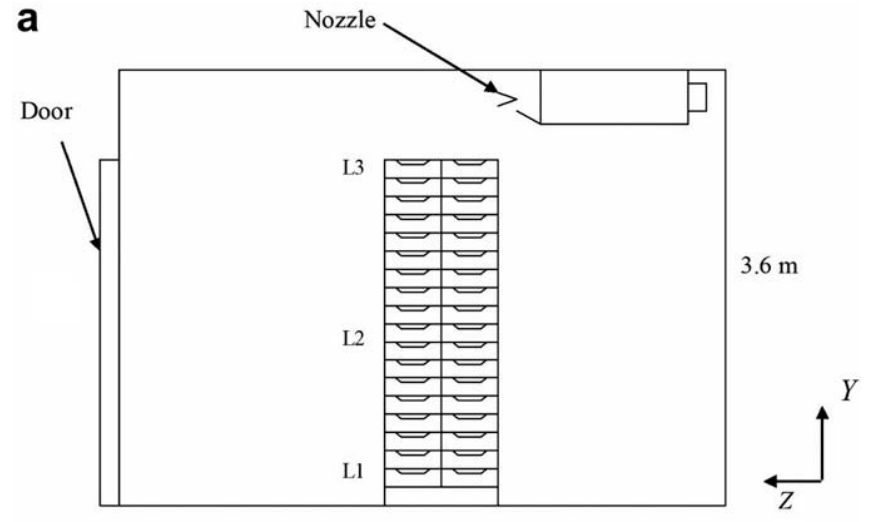

b

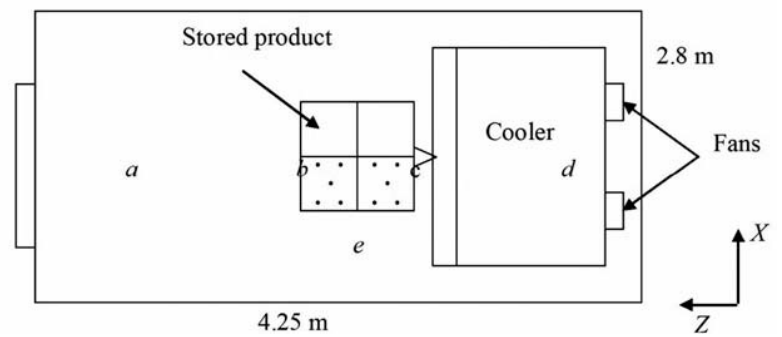

Fig. 1. Cold storage room (a) side view (b) top view; $(\bullet$ ), positions of thermocouples inside the stack, on different levels on the spheres and in the air (L1, L2 and L3); $a, b$ $c, d$ and $e$ are measurement positions for vertical velocity profile of the cooling air.

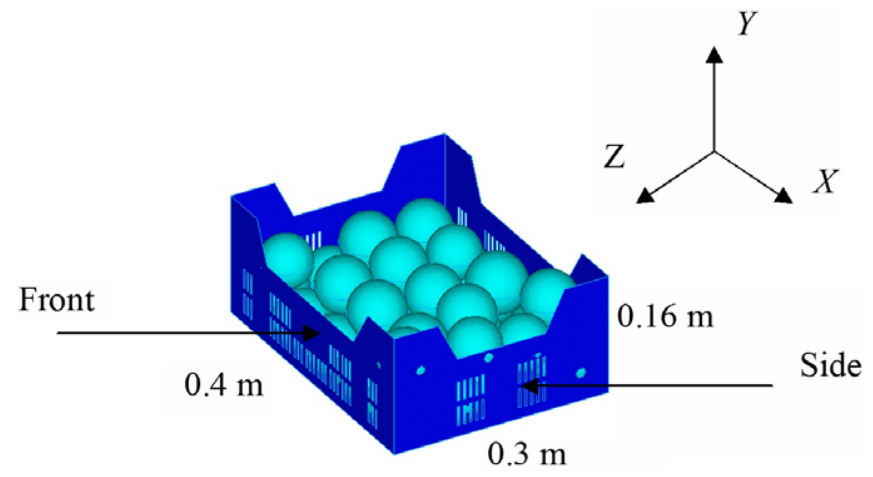

Fig. 2. Vented EPS box loaded with 32 spheres of $75 \mathrm{~mm}$ diameter, used for DE-CFD simulations.

measuring temperature and humidity, respectively. The temperature sensors measured the cooling air and coolant temperatures at the entrance and exit of the cooler. The room was loaded with 72 vented EPS (Euro Pool System, Leidschendam, The Netherlands) boxes of dimensions $30 \times 40 \times 16 \mathrm{~cm}$ were used (Fig. 2). Each box was filled with 32 artificial hollow polyvinyl chloride (PVC) plastic spheres of $75 \mathrm{~mm}$ diameter. The artificial PVC spheres were filled with water and assumed to represent the real fruit.

\subsection{CFD model formulation}

The CFD code used for this work was Fluent 6.3.28 (Fluent Inc. Lebanon, USA). The continuous air flow was solved using Reynoldsaveraged fluid flow equations. The position of the water droplets (discrete phase) in the continuous air stream was tracked using a Lagrangian particle tracking multiphase flow model. The model took into account two-way coupling with turbulent dispersion and droplet evaporation. Two-way coupling incorporates the effect of the continuous air flow on the flow of the discrete droplet phase, and the effect of discrete droplet flow on the flow of the continuous air phase.

\subsubsection{Governing equations}

2.2.1.1. Continuous phase. In Cartesian coordinates, for flow in a porous media, the Reynolds-averaged fluid flow equations based on interstitial fluid velocity are as follows (Nakayama and Kuwahara, 1999; Antohe and Lage, 1997):

$$
\begin{aligned}
& \frac{\partial\left(\rho_{\mathrm{a}}\right)}{\partial t}+\frac{\partial\left(\rho_{\mathrm{a}} u_{i}\right)}{\partial x_{i}}=S_{\mathrm{m}} \\
& \begin{aligned}
\frac{\partial\left(\rho_{\mathrm{a}} u_{i}\right)}{\partial t}+\frac{\partial\left(\rho_{\mathrm{a}} u_{i} u_{j}\right)}{\partial x_{j}}= & -\frac{\partial(p)}{\partial x_{i}}+\frac{\partial}{\partial x_{j}}\left[\mu_{\mathrm{a}}\left(\frac{\partial\left(u_{i}\right)}{\partial x_{j}}+\frac{\partial\left(u_{j}\right)}{\partial x_{i}}\right)\right] \\
& -\frac{\partial}{\partial x_{j}}\left(\rho_{\mathrm{a}} \overline{u_{i}^{\prime} u_{j}^{\prime}}\right)-\delta_{i 3}\left[1-\alpha\left(T-T_{\mathrm{o}}\right)\right] \rho_{\mathrm{a}} g+S_{\mathrm{u}}
\end{aligned}
\end{aligned}
$$

By assuming a local thermal equilibrium between the air and the porous solid matrix (the temperature of the air and the porous solid matrix is assumed to be equal), the energy equation is

$$
\begin{gathered}
\frac{\partial}{\partial t}\left(\phi \rho_{\mathrm{a}} C_{p \mathrm{a}} T+(1-\phi) \rho_{p} C_{\mathrm{pp}} T\right)+\phi \frac{\partial}{x_{j}}\left(\rho_{\mathrm{a}} C_{p \mathrm{a}} u_{j} T\right) \\
=\frac{\partial}{\partial x_{\mathrm{j}}}\left[\lambda_{\mathrm{eff}}\left(\frac{\partial T}{\partial x_{j}}\right)\right]-\phi \frac{\partial}{\partial x_{j}}\left(\rho_{\mathrm{a}} C_{\mathrm{pa}} \overline{u^{\prime} T^{\prime}}\right)+S_{\mathrm{e}}
\end{gathered}
$$

In most cases of flow in fluid saturated porous media the assumption of local thermal equilibrium is valid (Nakayama and Kuwahara, 2005); and, this assumption has been used by several previous studies (Nakayama and Kuwahara, 1999; Antohe and Lage, 1997; Masuoka and Takatsu, 1996; Chourasia and Goswami, 2007). However, the limitation of such thermal equilibrium assumption for a flow through a porous solid matrix with a heat generation has been discussed (Laguerre et al., 2008; Verboven et al., 2006). In this mod$\mathrm{el}$, the heat generation due to the respiration and the water evaporation from the surface of the stored product were not included. The transport equation for vapour mass fraction is

$$
\begin{aligned}
\phi \frac{\partial\left(\rho_{\mathrm{a}} Y_{v}\right)}{\partial t}+\phi \frac{\partial}{\partial x_{j}}\left(\rho_{\mathrm{a}} u_{j} Y_{v}\right)= & \phi \frac{\partial}{\partial x_{j}}\left[\rho_{\mathrm{a}} D_{a}\left(\frac{\partial\left(Y_{v}\right)}{\partial x_{j}}\right)\right]-\phi \frac{\partial}{\partial x_{j}} \\
& \times\left(\rho_{\mathrm{a}} \overline{u_{j}^{\prime} Y^{\prime}}\right)+S_{m}
\end{aligned}
$$

The specific Reynolds stress term $\left(\overline{u_{i}^{\prime} u_{j}^{\prime}}\right)$ in Eq. (2) and the specific Reynolds flux terms $\overline{u_{j}^{\prime} T^{\prime}}$ and $\overline{u_{j}^{\prime} Y_{v}^{\prime}}$ in Eqs. (3) and (4) can be approximated by (Versteeg and Malalasekera, 1995; Wilcox, 2000; Gouesbet and Berlemont, 1999)

$$
\begin{aligned}
& \overline{\overline{u_{i}^{\prime} u_{j}^{\prime}}}=-\frac{\mu_{t}}{\rho_{\mathrm{a}}}\left(\frac{\partial u_{i}}{\partial x_{j}}+\frac{\partial u_{j}}{\partial x_{i}}\right)+\frac{2}{3} k \delta_{i j} \\
& \overline{u_{j}^{\prime} T^{\prime}}=-\frac{\mu_{t}}{\rho_{\mathrm{a}} \operatorname{Pr}_{t}}\left(\frac{\partial T}{\partial x_{j}}\right) \\
& \overline{u_{j}^{\prime} Y_{v}^{\prime}}=-\frac{\mu_{t}}{\rho_{\mathrm{a}} S c_{\mathrm{t}}}\left(\frac{\partial Y_{v}}{\partial x_{j}}\right)
\end{aligned}
$$

where the effective thermal conductivity and heat capacity are estimated using: $\quad \lambda_{\text {eff }}=\phi \lambda_{\mathrm{a}}+(1-\phi) \lambda_{\mathrm{a}}, \quad C_{\mathrm{peff}}=\phi C_{\mathrm{pa}}+(1-\phi) C_{\mathrm{pp}}$, respectively) (Carson, 2006; Bertola and Cafaro, 2006); $\operatorname{Pr}_{t}$ is the turbulent Prandtl number $\left(\operatorname{Pr}_{t}=\frac{C_{\mathrm{pa}} \mu_{\mathrm{a}}}{\lambda_{\mathrm{a}}}\right) ; S c_{\mathrm{t}}$ is the turbulent Schmidt numbers $\left(S c_{t}=\frac{\mu_{\mathrm{t}}}{\rho_{\mathrm{a}} D_{\mathrm{t}}}\right)$.

For closure of these equations, the appropriate turbulence models are used. The Boussinesq hypothesis (Eq. (5)), that relates the Reynolds stress term to the mean velocity gradient assumes the turbulent viscosity to be isotropic, which is not strictly true. The Boussinesq hypothesis is used in the Spalart-Allmaras turbulence model, $k-\varepsilon$ turbulence model and $k-\omega$ turbulence model. The alternative approach is to use a turbulence model that takes into account the anisotropy of the Reynolds stress term. The 
Reynolds stress turbulence model is an alternative but it increases the computational cost. In many engineering applications, models based on the Boussinesq approximation perform very well, and the additional computational expense of the Reynolds stress model is not justified. However, there are some applications where the Reynolds stress turbulence model is clearly superior for situations in which the anisotropy of turbulence has a dominant effect on the mean flow. Such cases include flows with sudden change in mean strain rate, flow over curved surfaces and flow in rotating fluids (Anonymous, 2006; Wilcox, 2000). Alvarez and Flick (1999) observed turbulence generation behind the stacked product and later Alvarez et al. (2003) proposed a one equation semi-empirical model for two-dimensional turbulence flow through porous medium that took into account this turbulence generation. However, previous studies on airflow, heat and mass transfer in loaded refrigerated systems used the porous medium approach and treated turbulence using conventional turbulence models that are employed in Reynolds-average approach (standard $\mathrm{k}-\varepsilon$, RNG $k-\varepsilon$ and Reynolds stress) (Hoang et al., 2000; Mirade and Picgirard, 2006; Moureh and Flick, 2004; Nahor et al. 2005). Generally, the accuracy of these models was reasonable. In this study, different two-equation eddyviscosity turbulence models ${ }^{*}$ (standard $\mathrm{k}-\varepsilon$, RNG $\mathrm{k}-\varepsilon$, realizable $\mathrm{k}-\varepsilon$, standard $\mathrm{k}-\omega$ and shear stress transport (SST- k- $\omega$ ) were compared. For standard- k- $\varepsilon$, RNG- k- $\varepsilon$, realizable- k- $\varepsilon$, standard- k- $\omega$ and SST- $\mathrm{k}-\omega$ turbulence models, the overall average relative error of the predicted velocity relative to the measured values inside a loaded cool room was $24.3 \%, 22.4 \%, 23.5 \%$ and $18.2 \%$, respectively. After comparing the accuracy and the convergence of the solution, SST- $\mathrm{k}-\omega$ model that uses $\mathrm{k}-\omega$ in the wall region and $\mathrm{k}-\varepsilon$ in the bulk flow region (Menter, 1994) was used. In this turbulence model, the eddy-viscosity of the conventional two-equation models is modified to account for the transport of the principal turbulent shear stress. The values of $P r_{t}$ and $S c_{t}$ that were used in this model were 0.85 and 0.7 , respectively.

The term $S_{\mathrm{m}}$ takes into account the evaporation from the discrete droplet phase $\left(S_{\mathrm{md}}\right)$ and the condensation/evaporation of water vapour on the cooling coils $\left(S_{\mathrm{mc}}\right)$. The term $S_{\mathrm{u}}$ contains the resistance of the porous medium to airflow $\left(S_{\text {up }}\right)$ and the momentum exchange with the discrete phase $\left(S_{\mathrm{ud}}\right)$. The term $S_{\mathrm{e}}$ consists of the heat exchange on the cooler $\left(S_{\mathrm{ec}}\right)$ and the heat exchange with the discrete phase $\left(S_{\text {ed }}\right)$.The model consisted of the following three zones. The product zone, represented the region that was occupied by the loaded boxes, it did not include the free air space between two successive boxes when it was loaded one above the other; in this zone, the values of $S_{\mathrm{mc}}$ and $S_{\mathrm{ec}}$ were zero. The cooler zone, represented the volume occupied by the cooler; in this zone, the values of $S_{\mathrm{md}}, S_{\mathrm{ud}}$ and $S_{\text {ed }}$ were zero. The free air zone, consisted of the region that was not included in product and cooler zones; in this zone, only the sources related to the discrete droplet phase was relevant (the values of $S_{\mathrm{mc}}, S_{\mathrm{up}}$ and $S_{\mathrm{ec}}$ were zero).

The stored product and the cooler were modelled as a porous medium with the corresponding mass, momentum and heat sources/sink. The source due to the airflow resistance of the product was determined using the Darcy-Forchheimer equation (Forchheimer, 1901):

$S_{\text {upi }}=-\phi \frac{\mu_{\mathrm{a}}}{K} u_{i}-\phi^{2} \frac{1}{2} \beta \rho_{\mathrm{a}}\left(u_{j} u_{j}\right)^{1 / 2} u_{i}$

The first term on the right-hand side of Eq. (8) is called the Darcy term and accounts for the viscous drag, while the second term accounts the drag due to the inertial effect. In the case of the cooler the same equation (Eq. (8)) was used; however, the Darcy term was neglected and the parameter $\beta$ was calculated by taking into account losses due to wall friction, entrance and exit and acceleration/deceleration effects (Tso et al., 2006). The source due to the heat loss to the cooler was calculated using:
$S_{\text {ec }}=\frac{Q_{\mathrm{c}}}{V_{\text {cell }}}=\frac{-h_{\mathrm{hc}} A_{\mathrm{c}}\left(T_{\mathrm{a}}-T_{\mathrm{c}}\right)}{V_{\text {cell }}}$

To calculate the mass source due to condensation/evaporation of water vapour on the cooler, the following equation was used:

$S_{\mathrm{mc}}=\frac{m_{\mathrm{c}}}{V_{\text {cell }}}=\frac{-h_{\mathrm{mc}} A_{\mathrm{c}} \rho_{\mathrm{da}}\left(X_{v_{\mathrm{a}}}-X_{v_{\mathrm{c}}}\right)}{V_{\text {cell }}}$

The mass transfer coefficient $\left(h_{\mathrm{mc}}\right)$ was calculated according Lewis correlation of heat and mass transfer (Tso et al., 2006). The details about the exchange of mass, momentum and heat between the continuous and the discrete droplet phases $\left(S_{\mathrm{md}}, S_{\mathrm{ud}}\right.$ and $\left.S_{\text {ed }}\right)$ are outlined in Section 2.2.1.2.

2.2.1.2. Discrete phase. For a discrete droplet travelling in a continuous fluid medium, the forces acting on the droplet which affect the droplet acceleration are due to the difference in velocity between the droplet and the fluid, and due to the displacement of the fluid particle. Neglecting all the other forces except the drag and buoyancy forces, the equation of motion for the droplet can be written as:

$$
\begin{aligned}
m_{\mathrm{d}} \frac{\mathrm{d} v_{\mathrm{d} i}}{\mathrm{~d} t}= & \frac{1}{8} \pi \rho_{\mathrm{a}} d^{2} C_{\mathrm{d}}\left(\left(v_{\mathrm{a} j}-v_{\mathrm{d} j}\right)\left(v_{\mathrm{a} j}-v_{\mathrm{d} j}\right)\right)^{1 / 2}\left(v_{\mathrm{a}_{i}}-v_{\mathrm{d} i}\right) \\
& +\frac{1}{6} \pi d^{3}\left(\rho_{\mathrm{d}}-\rho_{\mathrm{a}}\right) g_{i}
\end{aligned}
$$

The drag coefficient $\left(C_{\mathrm{d}}\right)$ was calculated using an empirical correlation developed by Haider and Levenspiel (Haider and Levenspiel, 1989):

$C_{\mathrm{d}}=\frac{24}{\operatorname{Re}}\left(1+0.186 \operatorname{Re}^{0.653}\right)+\frac{0.437 R e}{7135+\operatorname{Re}}$

where Re is the particle Reynolds number, defined by:

$R e=\frac{\rho_{\mathrm{a}}\left(\left(v_{\mathrm{a} j}-v_{\mathrm{dj}}\right)\left(v_{\mathrm{a} j}-v_{\mathrm{dj}}\right)\right)^{1 / 2} \mathrm{~d}}{\mu_{\mathrm{a}}}$

The droplet displacement $\left(x_{i}\right)$ is calculated using forward Euler integration of the particle velocity over time step, $\delta t$.

$x_{i}^{n}=x_{i}^{o}+v_{\mathrm{d} i} \delta t$

The droplet velocity $\left(v_{\mathrm{d} i}\right)$ at the beginning of the time step is assumed to prevail over the entire step. At the end of each time step, the new particle velocity is calculated from Eq. (11), taking into account turbulent dispersion of the droplets. The turbulent dispersion of the droplets was modelled using the relations that were developed by Gosman and Ioannides (1981). The droplet is always assumed to interact with a series of turbulent eddies and as long as droplet/eddy interaction time is less than the eddy life time the turbulent fluid velocity prevails. The detailed equations of the turbulent dispersion of droplets can be found in Delele et al. (2007b).

The heat balance that relates the sensible heat change in the droplet to the convective and latent heat transfer between the droplet and the continuous phase reads:

$m_{\mathrm{d}} C_{\mathrm{pd}} \frac{\mathrm{d} T_{\mathrm{d}}}{\mathrm{d} t}=\pi \mathrm{d} N u \lambda_{a}\left(T_{\mathrm{a}}-T_{\mathrm{d}}\right)+L\left(\frac{\mathrm{d} m_{\mathrm{d}}}{\mathrm{d} t}\right)$

The Nusselt number $(\mathrm{Nu})$ is determined using the correlation of Ranz and Marshall (1952a, 1952b):

$N u=\frac{h_{\mathrm{ha}} \mathrm{d}}{\lambda_{\mathrm{a}}}=2+0.6 \operatorname{Re}^{0.5} \operatorname{Pr}^{0.33}$

For a droplet below its boiling point, the rate of evaporation of the droplets to the air is governed by gradient diffusion:

$\frac{\mathrm{d} m_{\mathrm{d}}}{\mathrm{d} t}=-\pi d \mathrm{D}_{\mathrm{a}} \operatorname{ShM} \mathrm{Mv}_{\mathrm{wv}}\left(\mathrm{Co}_{\mathrm{v}, \mathrm{s}}-\mathrm{Co}_{\mathrm{v}, \infty}\right)$ 
The Sherwood number $(S h)$ is calculated from the heat and mass transfer analogy:

$S h=\frac{h_{\mathrm{ma}} \mathrm{d}}{D_{\mathrm{a}}}=2+0.6 R e^{0.5} S c^{0.33}$

The contribution of the droplet to the source/sink terms $\left(S_{\mathrm{md}}, S_{\mathrm{ud}}\right.$ and $S_{\text {ed }}$ ) in Eqs. (1)-(4) represent the integrated effects of droplet mass, momentum and energy exchange with the continuous phase. These Eulerian variables are calculated from the Lagrangian droplet variables by volume averaging the contributions from all individual droplets within the cell volume as follows:

$S_{\mathrm{md}}=-\frac{1}{V_{\text {cell }}} \sum_{n=1}^{n_{\mathrm{d}}} \frac{\mathrm{d} m_{\mathrm{d}}}{\mathrm{d} t}$

$S_{\mathrm{udi}}=-\frac{1}{8} \pi \rho_{\mathrm{a}} d^{2} C_{\mathrm{d}}\left(\left(v_{\mathrm{a} j}-v_{\mathrm{d} j}\right)\left(v_{\mathrm{aj}}-v_{\mathrm{d} j}\right)\right)^{1 / 2}\left(v_{\mathrm{a}_{i}}-v_{\mathrm{d} i}\right)-\frac{1}{V_{\text {cell }}} \sum_{n=1}^{n_{\mathrm{d}}} \frac{\mathrm{d} m_{\mathrm{d}}}{\mathrm{d} t} v_{\mathrm{d} j}$

$S_{\text {ed }}=-\frac{1}{V_{\text {cell }}} \sum_{n=1}^{n_{d}} \pi d N u \lambda_{a}\left(T_{a}-T_{d}\right)-\frac{1}{V_{\text {cell }}} \sum_{n=1}^{n_{d}} C_{p v} \frac{d m_{d}}{d t} T_{d}$

The first and second terms in right hand side (RHS) of Eq. (20) represent the momentum exchange between the two phases without any phase change and the momentum flux ejected by the droplet during its vaporization, respectively. The first and second terms in the RHS of Eq. (21) represent the convective heat transfer and heat released by the droplets into the continuous phase as a result of mass transfer accompanying the change from the liquid state to the gaseous state, respectively.

\subsubsection{Geometry and boundary conditions}

The domain used for the simulation had the size of the refrigerated room along with the fan and the heat exchanger (Fig. 1). The fan was modelled as a fan boundary with a given pressure rise (28 $\mathrm{Pa}$ ), this was a lumped parameter model that did not give the detail flow behaviour through the fan blades but predicted the amount of flow through the fan. This approach did not also take into account the effect of the fan on the turbulence. All the solid surfaces in the room were taken as no slip walls. On the floor of the room and the walls that were exposed to the atmosphere a heat flux $\left(q_{\mathrm{fw}}=\frac{\lambda_{\mathrm{w}}}{t_{\mathrm{w}}}\left(T_{\mathrm{w}}-T\right)\right)$ from outside to the inside was applied. The outside wall/soil below the concrete floor temperature $T_{\mathrm{w}}$ was assumed to be the outside room temperature $\left(19^{\circ} \mathrm{C}\right)$ as the cold store is built indoor; the thermal conductivity $\lambda_{\mathrm{w}}$ of the insulation wall and the concrete floor were 0.022 and $2.6 \mathrm{~W} \mathrm{~m}^{-1}{ }^{\circ} \mathrm{C}^{-1}$, respectively; the thickness $t_{\mathrm{w}}$ of the insulation wall and the concrete floor were 0.12 and $0.1 \mathrm{~m}$, respectively. The wall boundary layer was treated using a standard wall function. The droplets that collide with the walls were assumed to be trapped. The heat of product respiration and evaporation of moisture from the product surface were not taken into account.

\subsubsection{Parameters and properties}

The pressure loss coefficients of the product handled in vented boxes were determined using a combined DE-CFD model that included the explicit geometry of both boxes and spheres (Delele et al., 2008). The calculated anisotropic pressure drop is shown in Fig. 3. The resulting coefficients are given in Table 1 . The details of the geometry of the boxes were also included in the model. To determine the effective thermo-physical properties of the water filled PVC spheres, a series model was assumed (density, $\rho_{\mathrm{fs}}=$ $1032.6 \mathrm{~kg} \mathrm{~m}^{-3}$; thermal conductivity, $\lambda_{f s}=0.468 \mathrm{~W} \mathrm{~m}^{-1}{ }^{\circ} \mathrm{C}^{-1}$ and specific heat, $C_{p f s}=3859.4 \mathrm{~J} \mathrm{~kg}^{-1}{ }^{\circ} \mathrm{C}^{-1}$ ). The free convection and the freezing effects of water inside the PVC spheres were neglected.

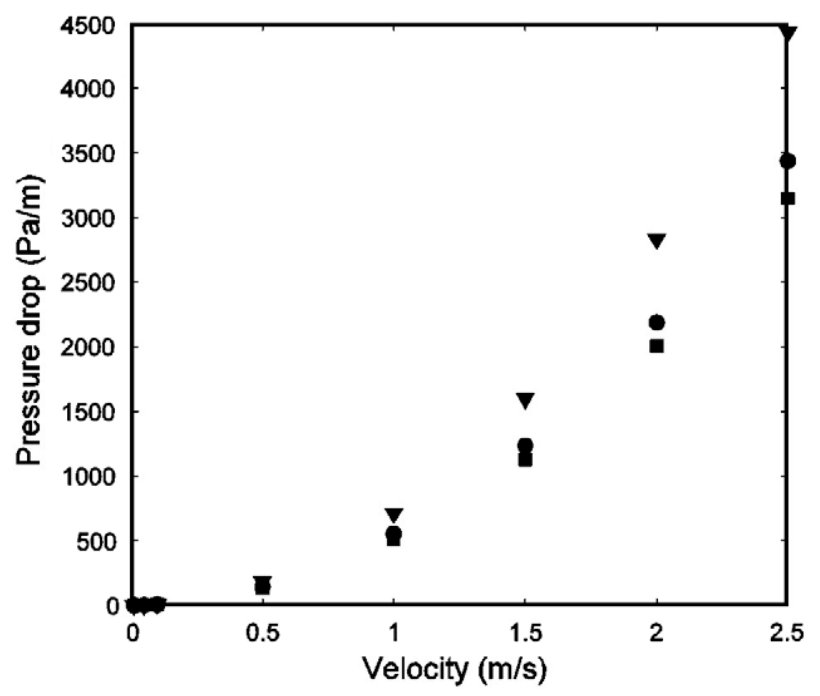

Fig. 3. Calculated anisotropic pressure drop using combined DE-CFD model for flow through vented EPS box loaded with 32 spheres of $75 \mathrm{~mm}$ diameter (Fig. 2), from different directions: Side-to-side ( $X$-direction), $\mathbf{\nabla}$; Front-to-back (Z-direction), Bottom-to-top (Y-direction),

Table 1

Parameters of the Darcy-Forchheimer equation (Eq. (8)) for vented EPS boxes loaded with 32 spheres of $75 \mathrm{~mm}$ diameter, obtained from DE-CFD simulations

\begin{tabular}{lll}
\hline Direction & $\frac{1}{K}\left(1 / \mathrm{m}^{2}\right)$ & $\beta(1 / \mathrm{m})$ \\
\hline$X$-direction & 138950 & 1179.97 \\
$Y$-direction & 117072 & 836.48 \\
$Z$-direction & 133278 & 913.29 \\
\hline
\end{tabular}

Table 2

Measured $D_{\mathrm{v} 10}, D_{\mathrm{v} 50}$ and $D_{\mathrm{v} 90}$ values of the humidifying nozzles for 40 bar and 80 bar water pressures

\begin{tabular}{lll}
\hline Diameter $(\mu \mathrm{m})$ & 40 bar & 80 bar \\
\hline$D_{\text {v10 }}$ & 14.20 & 12.90 \\
$D_{\text {v50 }}$ & 22.05 & 20.20 \\
$D_{\text {v90 }}$ & 41.10 & 39.01 \\
\hline
\end{tabular}

The droplets were injected with the appropriate nozzle characteristics (spray angle, direction and position, nozzle size, liquid flow rate and pressure and droplet diameter distribution). The humidifier nozzles were operated at $40 \mathrm{bar}\left(2.54 \mathrm{~L} \mathrm{~h}^{-1}\right)$ and 80 bar (3.59 $\mathrm{L} \mathrm{h}^{-1}$ ) pressure. The droplet size distribution produced by the humidifier was measured using a Malvern Spraytec (Malvern Instruments Ltd., Worcestershire, UK). The measured $D_{\mathrm{v} 10}, D_{\mathrm{v} 50}$ and $D_{\mathrm{v} 90}$ values (diameter at which a volume fraction of $10 \%, 50 \%$, and $90 \%$ is made up of droplets with diameters smaller than this value) are shown in Table 2 . The fit of the measured droplet size distribution to Rosin-Rammler distribution was not good; as a result, the Rosin-Rammler distribution was not used. The measured data was divided into 20 size classes and used as the droplet size distribution for the droplet injection. After evaluating the stability of the result to the number of droplets injected, injecting 30,000 droplets per nozzle was found sufficient.

\subsubsection{Solution procedure}

The computational domain was discretised using a tetrahedral hybrid mesh. After comparing the calculated results and the CPU time of the calculation for different mesh sizes, meshes with a maximum edge length of $0.01 \mathrm{~m}$ for the air gap space between 
two layers of boxes and $0.05 \mathrm{~m}$ for the other regions were selected. The total number of cells was $1,243,628$. Prior to the injection of the droplets the steady state simulation was converged to a normalized scaled residual below $10^{-4}$ of all equations. During the injection of the droplets, a transient simulation with a time step of $1 \mathrm{~s}$ and 50 iterations per time step was performed. During interval humidification, after the injection time of the droplets, the time step was gradually increased up to $60 \mathrm{~s}$. The calculation was done using a Pentium IV, 3.21 GHz WinXp workstation with 3.62GB Ram. A total CPU time of up to 9 days was needed.

\subsubsection{Validation method}

The air velocity, temperature, humidity and the amount of sprayed droplet deposited at different positions were measured in a storage room that was described in Section 2.1. By assuming symmetry, the measurements were taken only in half of the room.
The air velocity was measured using an air velocity transducer (TSI Incorporated, MN, USA). The operating range of the sensor is $0.05-2.5 \mathrm{~m} \mathrm{~s}^{-1}$. The factory calibrated accuracy of the sensor is $\pm 3 \%$ of the reading or $\pm 1 \%$ of the full range. The vertical velocity profile was measured at the following positions (Fig. 1): $1 \mathrm{~m}$ in front of the stack (position $a$ ), $1 \mathrm{~cm}$ in front of the stack (position $b$ ), $1 \mathrm{~cm}$ behind the stack (position $c$ ), $1 \mathrm{~m}$ behind the stack (position $d$ ) and $0.5 \mathrm{~m}$ from the side of the stack (position $e$ ). For measuring the temperature, type- $\mathrm{T}$ Teflon-insulated thermocouples with an accuracy of $\pm 0.4 \%$ were used (Omega Engineering, Inc., Stanford, USA). Inside a loaded room, the temperature in the air gap between two layers of boxes and surface temperature of the top water filled artificial spheres inside the lower box were monitored. The measurement was taken at three vertical positions ( $\mathrm{L} 1=0.24 \mathrm{~m}, \mathrm{~L} 2=1.39 \mathrm{~m}$ and $\mathrm{L} 3=2.73 \mathrm{~m}$ from the floor). At every vertical position 20 thermocouples (10 in the air gap and 10 on the

a

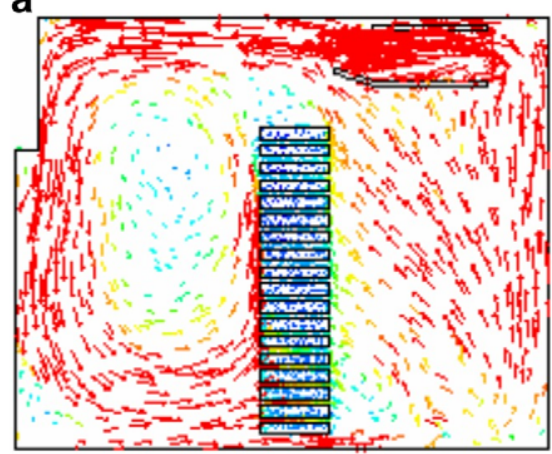

b

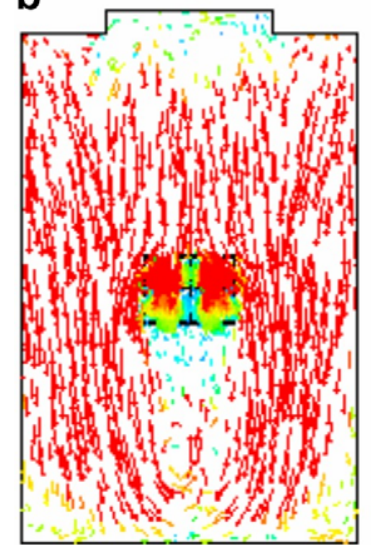

e

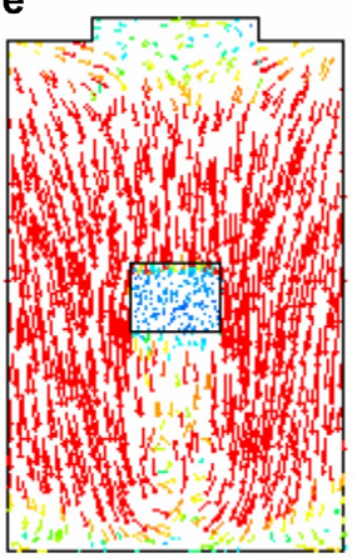

C

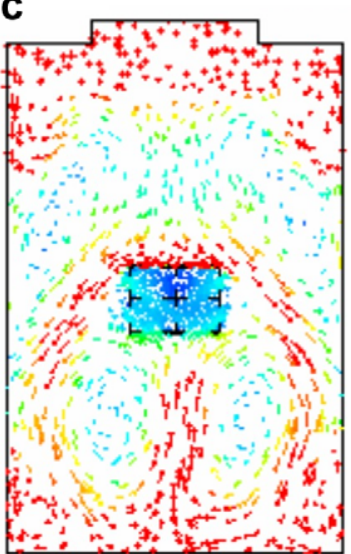

f

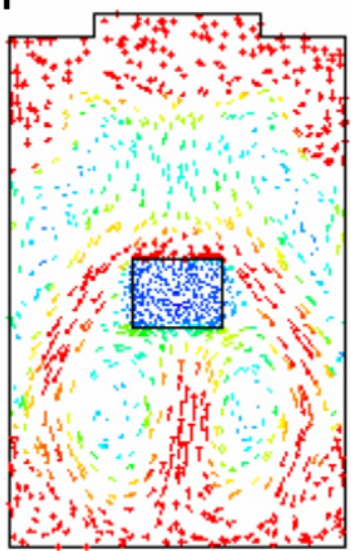

d

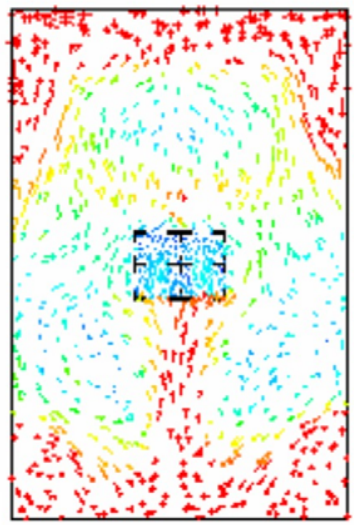

g

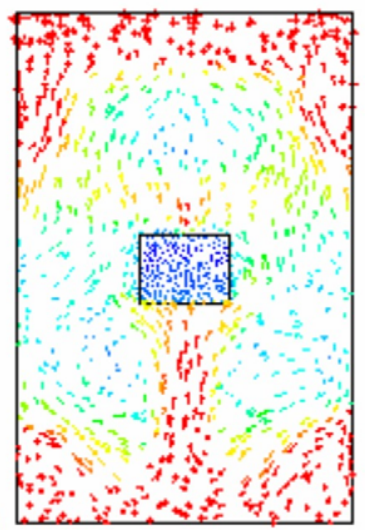

Fig. 4. Air velocity vectors in a loaded room: vertical mid-plane (a); horizontal planes: air gap above the bottom box (b), air gap at the centre of the stack (c), above the top box (d), centre of the bottom box (e), centre of the 9 th box (f), centre of the top box (g); $0.5 \mathrm{~m} / \mathrm{s}$ (red), $0 \mathrm{~m} / \mathrm{s}$ (blue). 
sphere surface) were used (Fig. 1). There was a $2 \mathrm{~cm}$ gap between the surface and the air gap thermocouples.

The humidity was determined by measuring the dry bulb and the dew point temperatures of the cooling air using a PT100 and a chilled-mirror dew point meter (General Eastern Instruments, MA, USA), respectively. The humidity was measured in the air gap between boxes at $X=1.6 \mathrm{~m}, Y=2.42 \mathrm{~m}$ and $Z=2.25 \mathrm{~m}$. To quantify the amount of sprayed droplets deposited on top, side and inside the stack and floor of the loaded room a $3 \mathrm{~cm}$ by $3 \mathrm{~cm}$ piece of cotton was used. The piece of cotton was weighed before and after 22 $\mathrm{hr}$ of interval ( $1 \mathrm{~min}$ on and $15 \mathrm{~min}$ off) humidification.

\subsubsection{Simulation cases}

Simulation was performed for the following cases:Case 1, a steady state simulation of the air velocity distribution in the room. This was used as an initial velocity condition of the other cases. The result of this simulation was also used to study and validate the predicted cooling air velocity distribution.Case 2 , a transient simulation of room cooling with and without interval humidification ( $1 \mathrm{~min}$ on and $10 \mathrm{~min}$ off); initially the room was set at $20^{\circ} \mathrm{C}$ and $83.6 \% \mathrm{RH}$. This simulation was used to investigate and validate the effect of humidification during the cooling period on $\mathrm{RH}$ and cooling rate.Case 3 , a transient simulation with an interval humidification $1 \mathrm{~min}$ on and $15 \mathrm{~min}$ off; initially the room was set at -1 ${ }^{\circ} \mathrm{C}$ and $93.8 \% \mathrm{RH}$. This simulation was used to investigate and validate the effect of interval humidification on $\mathrm{RH}$ at sub-zero storage condition and effects of nozzle pressure, position and direction on droplet surface deposition. A design study was performed with this model.

\section{Results and discussion}

\subsection{Cooling air velocity distribution}

Predicted cooling air velocity vector fields in a loaded room are given in Fig. 4. The highest velocity was observed around the bottom region where it was in contact with the high velocity air jet from the cooler (Fig. 4b). The lowest velocity was observed around the centre of the stack (Fig. 4f). The air velocity in the air gap region was not uniform: a high velocity region around the centre of the box and a low velocity region around the contact plane of the two adjacent boxes were observed. This was due to the obstruction effect of the box walls above the porous region. However, the velocity in the porous region was relatively uniform and low (on the average, $0.0341 \mathrm{~m} \mathrm{~s}^{-1}$ (top) $-0.158 \mathrm{~m} \mathrm{~s}^{-1}$ (bottom)). There was a good agreement between the measured and predicted vertical velocity profiles (Fig. 5 ). The high and low velocity regions at the entrance and exit of the stack (Fig. 5b and c) corresponded to the air gap and porous regions, respectively. The overall average relative error $(E)$ was found to be $18.2 \%$. This is in the range of the previously reported relative errors of such CFD models of loaded cold storage rooms. Hoang et al. (2000), Nahor et al. (2005) and Mirade and Picgirard (2006) observed an average relative error of $26 \%, 22 \%$ and $21.6 \%$, respectively. The low error found in this case, therefore, indicates good agreement of the model with reality. $E$ was calculated using the following relation:

$E=\frac{1}{\mathrm{~N}} \sum \frac{\left|\mathrm{U}_{\mathrm{m}}-\mathrm{U}_{\mathrm{c}}\right|}{\mathrm{U}_{\mathrm{m}}} \times 100$

\subsection{Room cooling without humidification}

After 5, 12 and $20 \mathrm{~h}$ of cooling from an initial uniform temperature of $20^{\circ} \mathrm{C}$ and $\mathrm{RH}$ of $83.6 \%$, the predicted temperature and $\mathrm{RH}$ inside a loaded room during cooling to a set point of $-1{ }^{\circ} \mathrm{C}$ are given in Fig. 6. The hottest region was located around the top of the stack. Since it was in contact with the fresh cold air jet coming from the cooler, the bottom region of the stack was the coldest region. In the bottom region of the stack, the temperature of the air inside the air gap was lower than the surface temperature of the spheres. Up to the half cooling time (time necessary to reduce the temperature difference between initial and set point temperature by a half) of the hottest region, on the average the surface temperature was $0.92{ }^{\circ} \mathrm{C}$ higher than the air gap temperature. But in the middle and top regions, the difference between the two temperatures was very small. The correspondence with the
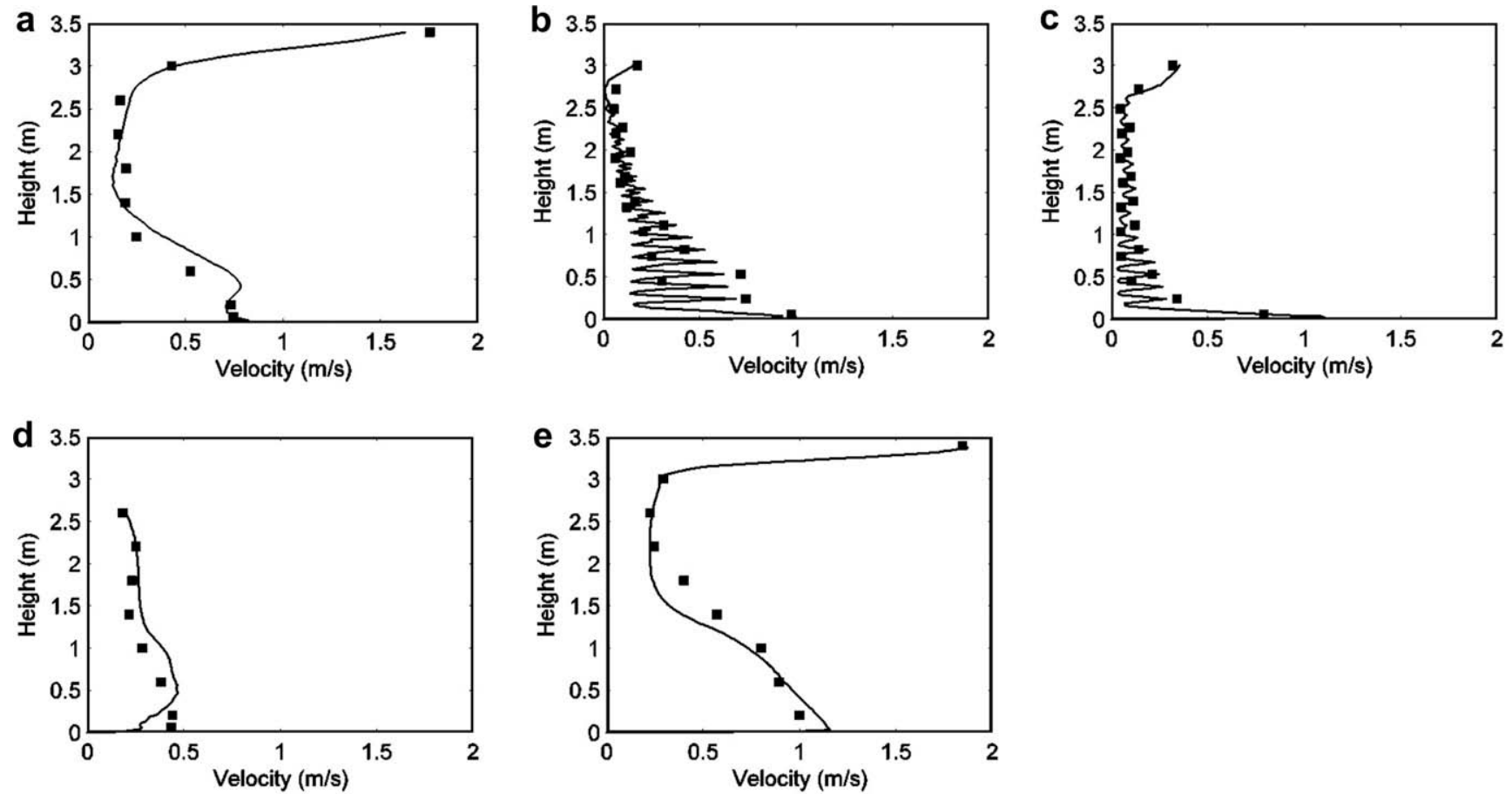

Fig. 5. Cooling air vertical velocity profile at different positions: - (predicted), a (measured); (a) position $a$, (b) position $b$, (c) position $c$, (d) position $d$, (e) position $e$. 
a
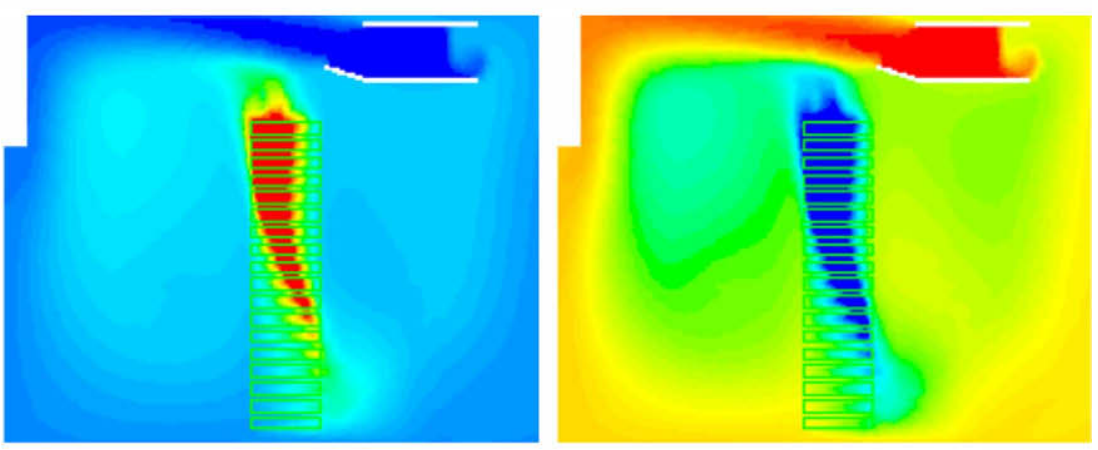

b
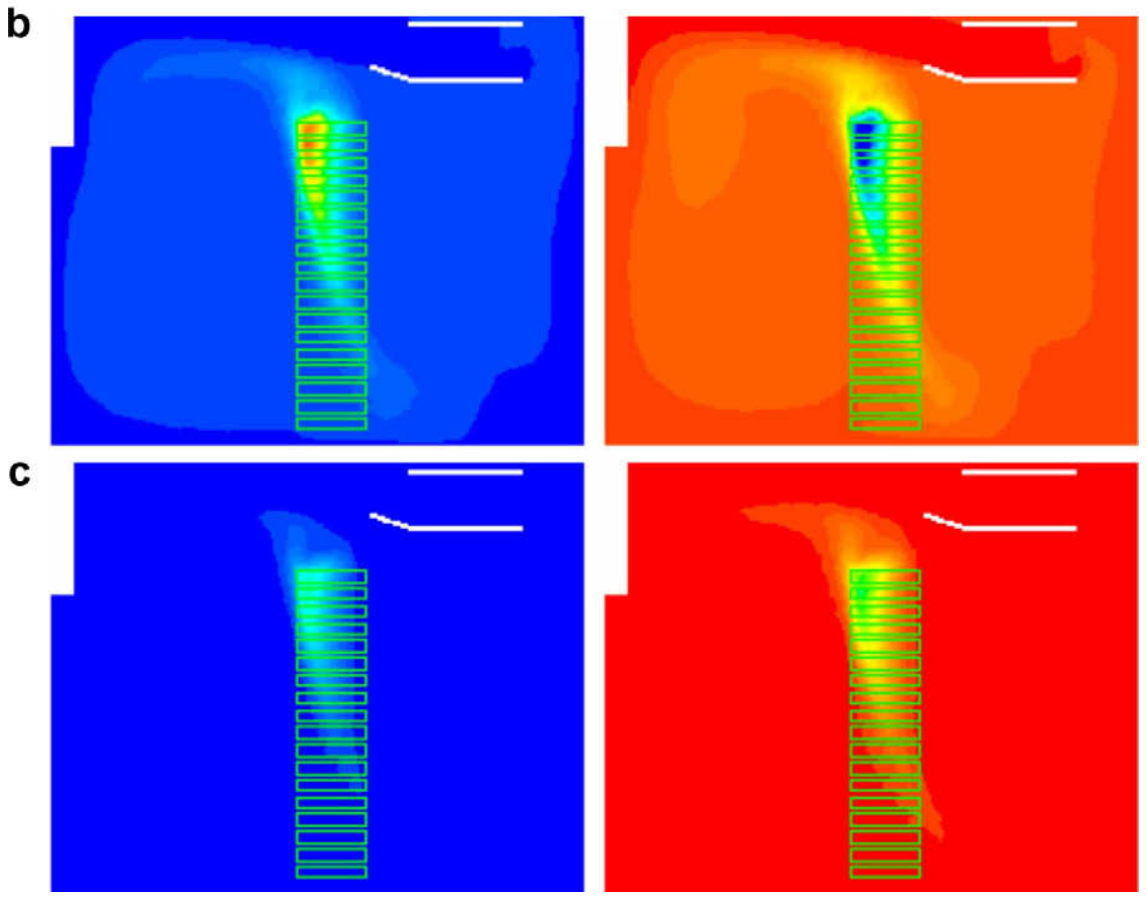

Fig. 6. CFD results of cooling without humidification: temperature (left) and humidity (right) contours of loaded room in the vertical mid-plane, after different times of cooling: (a) $5 \mathrm{~h}$; (b) $12 \mathrm{~h}$; (c) $20 \mathrm{~h}$, from an initial temperature of $20^{\circ} \mathrm{C}$ and $\mathrm{RH}$ of $83.6 \%$ : temperature: $10{ }^{\circ} \mathrm{C}$ (red), $-1{ }^{\circ} \mathrm{C}$ (blue); $\mathrm{RH}$ : $96 \%$ (red), $50 \%$ (blue). (For interpretation of the references to colour in this figure legend, the reader is referred to the web version of this article.)

measurement was generally very good and trends were correctly predicted (Fig. 7a). At every vertical position inside the stack, the average of the measured air gap and surface temperature was taken to compare to the calculated temperature.

The lowest RH is found in the hottest region in the stack. During the cooling period, initially there was a decrease in RH inside the stack region, followed by an increase. This showed that initially the loss of the water due to condensation on the cooling coil was the dominant factor that decreases the RH. Later, this effect was compensated by the decrease of stack temperature resulting in the desired increase of $\mathrm{RH}$. The model result was confirmed by the experiment (Fig. 7b).
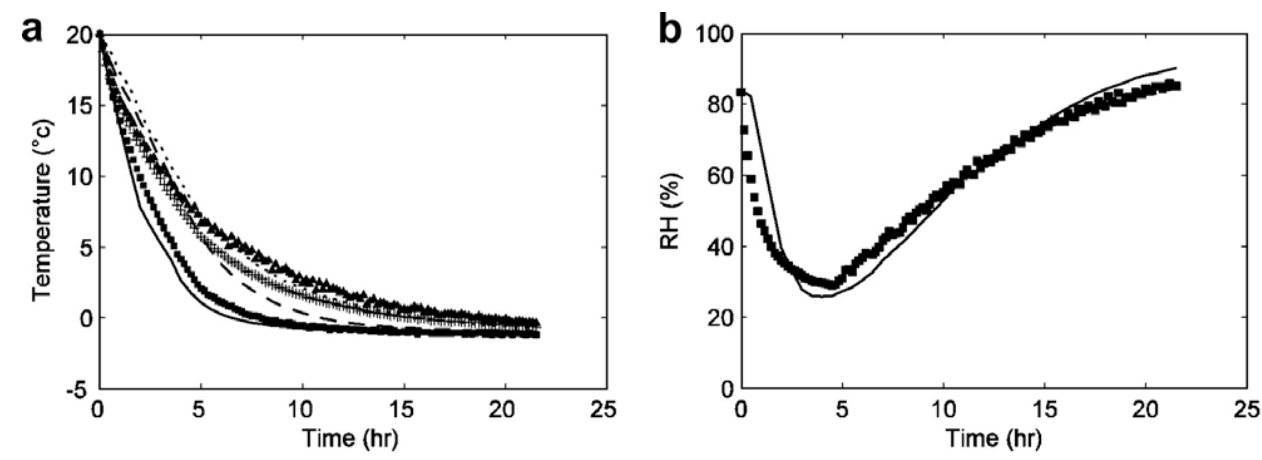

Fig. 7. Measured and predicted temperature and humidity profiles inside the stack, during cooling from an initial temperature of $20{ }^{\circ} \mathrm{C}$ and $\mathrm{RH}$ of $83.6 \%$ without humidification: (a) Temperature: - (predicted), - (measured) at $Y=0.24 \mathrm{~m} ;-$ (predicted), + (measured) at $Y=1.39 \mathrm{~m} ; \ldots$ (predicted), $\mathbf{\Delta}$ (measured) at $Y=2.73 \mathrm{~m} ;$ (b) RH: (predicted), $\mathbf{\square}$ (measured) at $Y=2.42$. 


\subsection{Room cooling with humidification}

Interval humidification during the cooling period increased the $\mathrm{RH}$ and cooling rate (Fig. 8). The measured and predicted temperature and $\mathrm{RH}$ inside the stack at $X=1.6 \mathrm{~m}, Y=2.42 \mathrm{~m}$ and $Z=2.25 \mathrm{~m}$ during cooling from an initial temperature of $20^{\circ} \mathrm{C}$ and $\mathrm{RH}$ of $83.6 \%$ to a set point of $-1{ }^{\circ} \mathrm{C}$ with and without humidification is given in Fig. 9. Due to the large water vapour pressure difference between the cooling air and the product surface, the highest weight loss is observed during the initial cooling period (Hamdami et al., 2004; Xu and Burfoot, 1999). Lowering the vapour pressure difference due to high $\mathrm{RH}$ and the shorter cooling time associated with the humidification system can minimize this weight loss. By assuming the product to be pears (cv. 'Conference'), the moisture loss from the stored product was approximately calculated after the simulation. The effect of this moisture loss on local temperature and humidity was not taken into account. This simplified assumption may not give a very accurate figure, but it is useful in analysing the trends of the moisture loss. During the initial $21.5 \mathrm{hr}$ of cooling period, the humidification helped decrease the weight loss from $4.22 \%$ to $3.09 \%$. Moreover, the humidification decreased the half cooling time by $15.78 \%$. The increase in cooling rate during spraying is attributed to the evaporative cooling effect.
The moisture loss was calculated using a lumped convection model, neglecting the moisture diffusion inside the product:

$m_{\mathrm{lp}}=h_{\mathrm{b}} A_{\mathrm{spec}}\left(P_{\mathrm{vp}}-P_{\mathrm{va}}\right)$

where the $P_{\mathrm{vp}}$ and $P_{\mathrm{va}}$ are the vapour pressures on the product surface and surrounding air, respectively. For thermodynamic equilibrium the surrounding air temperature approaches the product surface and the vapour is assumed to follow the ideal gas law:

$$
\begin{aligned}
& P_{\mathrm{vp}}=a_{\mathrm{w}} P_{\mathrm{sat}} \\
& P_{\mathrm{va}}=P_{\text {sat }}\left(\frac{\mathrm{RH}}{100}\right)
\end{aligned}
$$

The equation of the moisture loss becomes:

$$
m_{\mathrm{lp}}=h_{\mathrm{b}} A_{\mathrm{spec}} P_{\mathrm{sat}}\left(a_{\mathrm{w}}-\frac{\mathrm{RH}}{100}\right)
$$

The bulk product mass transfer coefficient $\left(h_{\mathrm{b}}\right)$ takes into account the resistance of the pear skin and the effect of the surrounding air:

$\frac{1}{h_{\mathrm{b}}}=\frac{1}{h_{\mathrm{s}}}+\frac{1}{h_{\mathrm{om}}}$ a

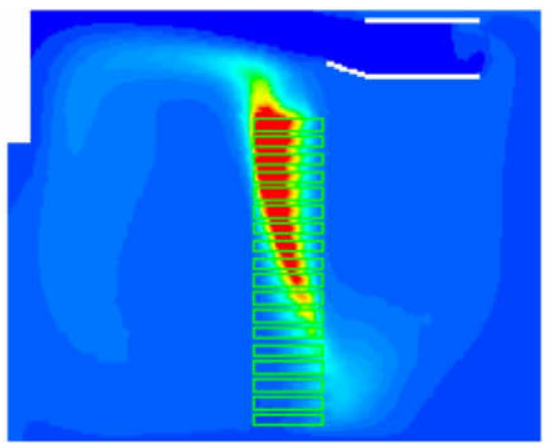

b

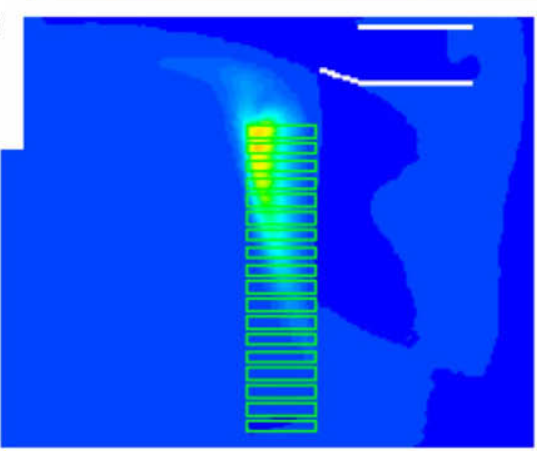

C

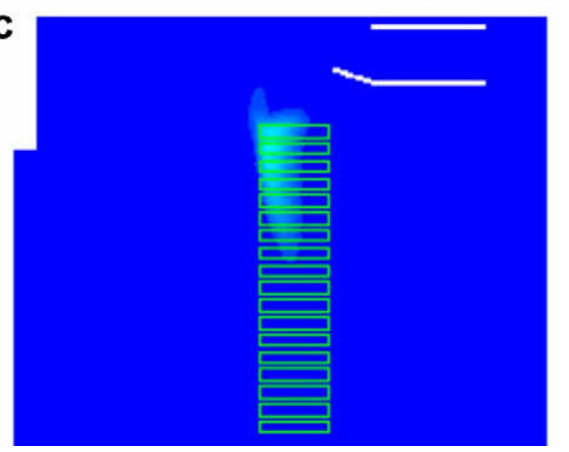

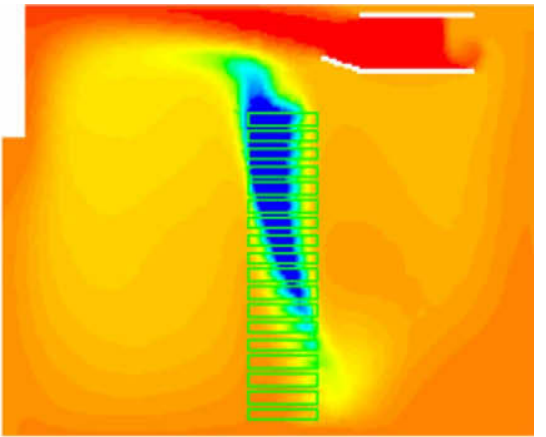
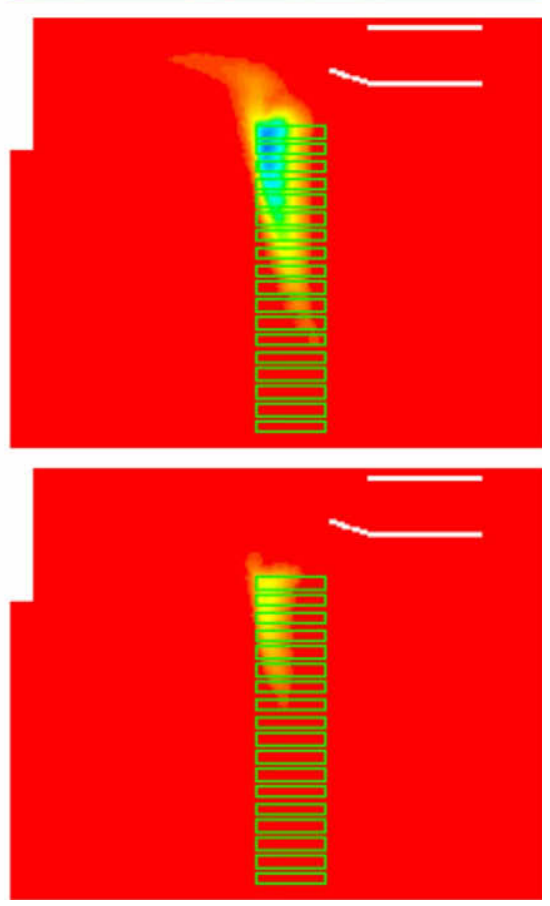

Fig. 8. CFD results of cooling with humidification: temperature (left) and humidity (right) contours of loaded room in the vertical mid-plane, with an interval humidification of $1 \mathrm{~min}$ on and $10 \mathrm{~min}$ off at 80 bar nozzle pressure, after different times of cooling: (a) $5 \mathrm{~h}$; (b) $12 \mathrm{~h}$; (c) $20 \mathrm{hr}$, from an initial temperature of $20{ }^{\circ} \mathrm{C}$ and $\mathrm{RH}$ of $83.6 \%$ : temperature: $10{ }^{\circ} \mathrm{C}$ (red), $-1{ }^{\circ} \mathrm{C}$ (blue); $\mathrm{RH}$ : $96 \%$ (red), $50 \%$ (blue). 

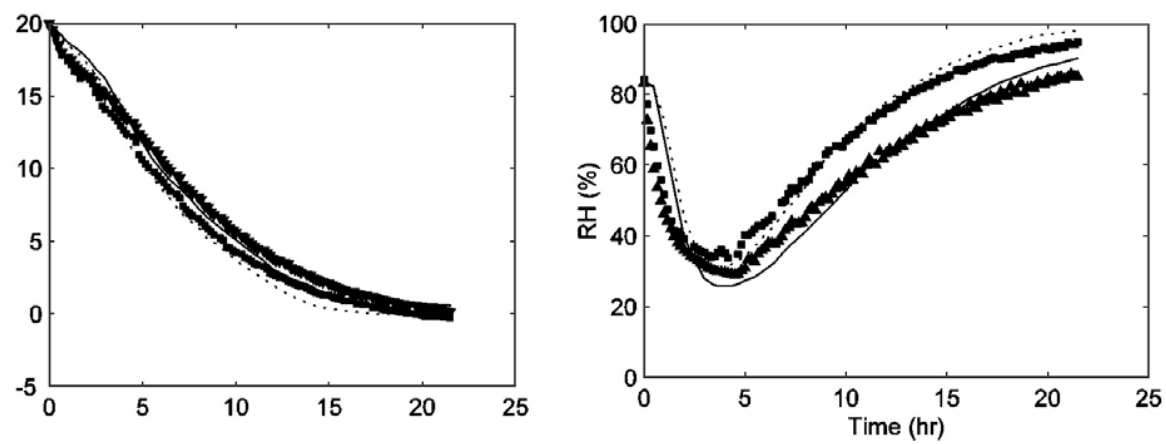

Fig. 9. Measured and predicted temperature (left) and $\mathrm{RH}$ (right) inside the stack at $X=1.6 \mathrm{~m}, Y=2.42 \mathrm{~m}$ and $Z=2.25 \mathrm{~m}$ during cooling from an initial temperature of $20{ }^{\circ} \mathrm{C}$ and RH of 83.6\%: - (predicted without humidification), ... (predicted with an interval humidification of 1 min on and 10 min off); $\Delta$ (measured without humidification), (measured with an interval humidification of $1 \mathrm{~min}$ on and $10 \mathrm{~min}$ off).

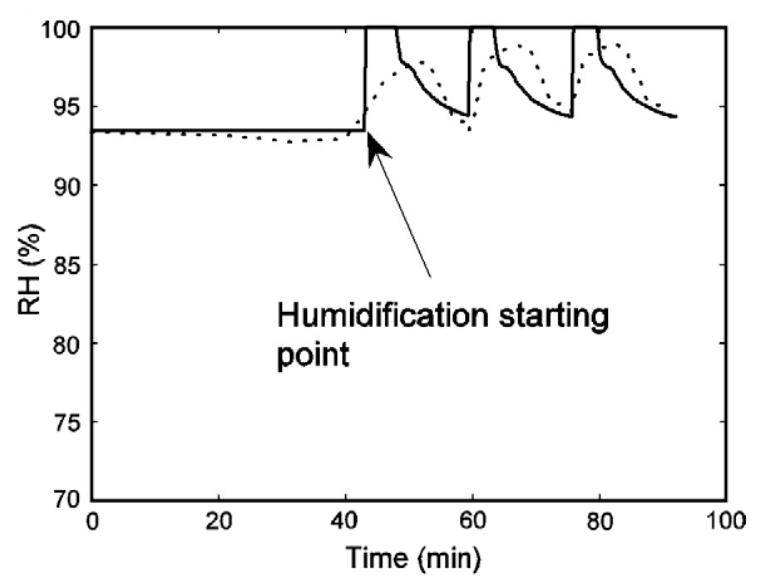

Fig. 10. Measured and predicted cooling air $\mathrm{RH}$ inside the stack at $X=1.6 \mathrm{~m}$, $Y=2.42 \mathrm{~m}$ and $Z=2.25 \mathrm{~m}$ with an interval humidification of $1 \mathrm{~min}$ on and $15 \mathrm{~min}$ off, for $-1{ }^{\circ} \mathrm{C}$ room temperature, one nozzle with 80 bar pressure: - (predicted), .. (measured).
The values of the water activity $\left(a_{w}\right)$, the skin resistance $\left(h_{\mathrm{s}}\right)$ and the average specific area $\left(A_{\text {spec }}\right)$ of the pear bulk were taken as $0.99,1.1$ $\times 10^{-14} \mathrm{~kg} \mathrm{~m}^{-2} \mathrm{~s}^{-1} \mathrm{~Pa}^{-1}$ and $93.4 \mathrm{~m}^{2} \mathrm{~m}^{-3}$, respectively (Nguyen et al., 2007). The external convective mass transfer coefficient $\left(h_{\mathrm{om}}\right)$ was determined from heat transfer coefficient $\left(h_{\mathrm{oh}}\right)$ using the Lewis analogy, for a forced convection through packed beds (Bird et al., 2002):

$$
\begin{aligned}
& N u=\left(2.19 \operatorname{Re}^{1 / 3}+0.78 \operatorname{Re}^{0.62}\right) \operatorname{Pr}^{1 / 3}=\frac{h_{\mathrm{ho}} D_{\mathrm{P}}}{\lambda_{a}(1-\phi) \varphi} \\
& h_{\mathrm{om}}=\frac{h_{\mathrm{oh}}}{\rho_{\mathrm{a}} C_{\mathrm{pa}} L e^{2 / 3}} \frac{V_{\mathrm{H}_{2} \mathrm{O}} \rho_{v_{\mathrm{sat}}}}{\mathrm{RT}}
\end{aligned}
$$

For bulk of pear at $-1{ }^{\circ} \mathrm{C}, \operatorname{Re}=\frac{D_{\mathrm{p}} u_{\mathrm{s}} \rho_{\mathrm{a}}}{(1-\phi) \mu_{a} \varphi}=313.3$ and $\operatorname{Pr}=\frac{C_{\mathrm{pa}} \mu_{\mathrm{a}}}{\lambda_{\mathrm{a}}}=0.71$; from the simulated result, the average superficial velocity $\left(u_{\mathrm{s}}\right)$ was taken as $0.035 \mathrm{~m} \mathrm{~s}^{-1}$; and the pear shape factor $(\varphi)$, the average equivalent diameter $\left(D_{\mathrm{p}}\right)$ and the porosity $(\phi)$ were taken as 0.92 , $65 \mathrm{~mm}$ and 0.4 , respectively (Nguyen et al., 2007).

\subsection{Humidification during the storage period}

Interval humidification of the room after it attained the storage temperature $\left(-1^{\circ} \mathrm{C}\right)$ can maintain the required high $\mathrm{RH}$ (Fig. 10).
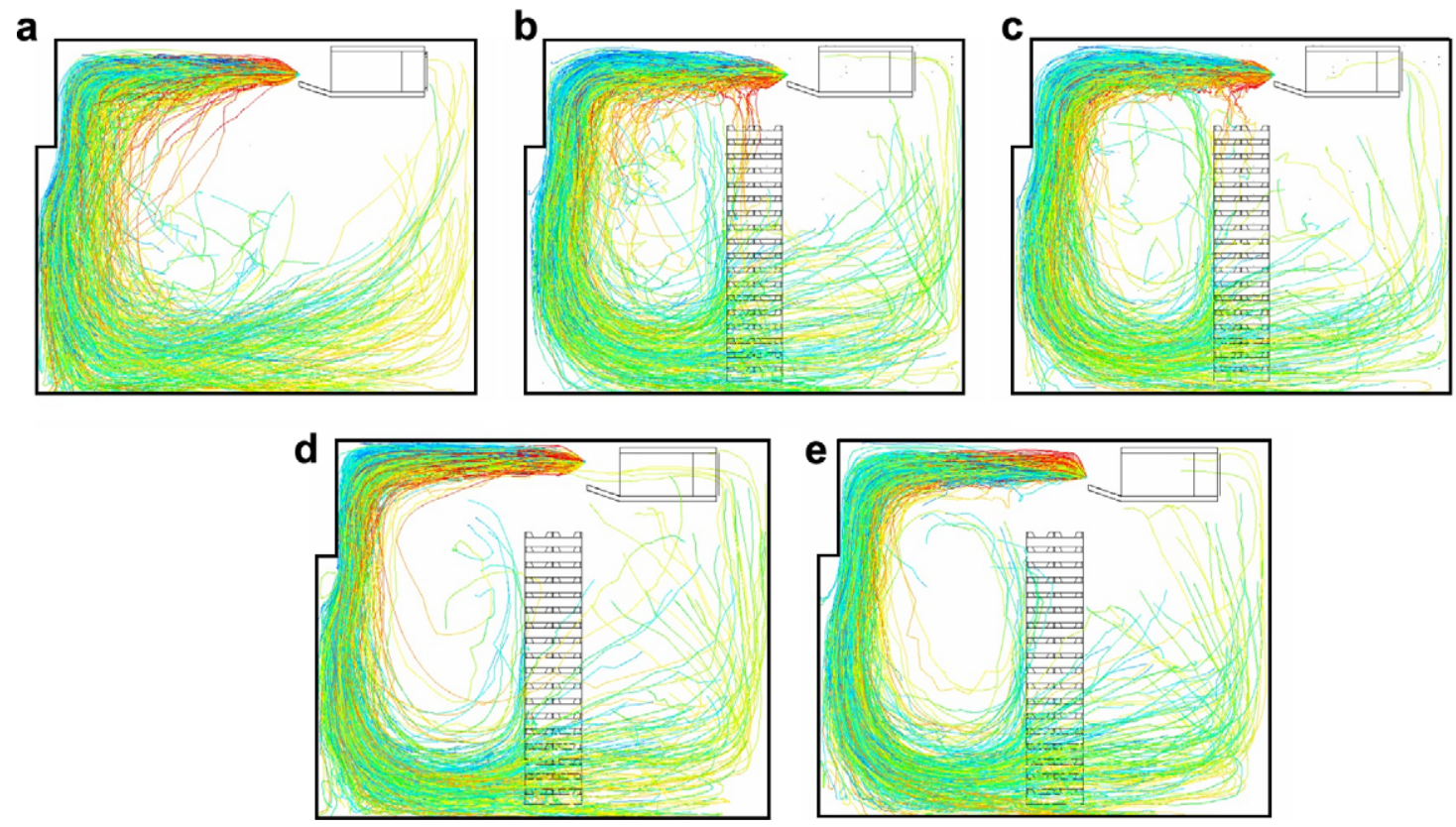

Fig. 11. Tracks of sprayed droplets for different nozzle pressure, vertical position and angle, using one nozzle, in a room with $-1{ }^{\circ} \mathrm{C}$ temperature and $93.8 \%$ RH with: $3.25 \mathrm{~m}$ vertical position and $0^{\circ}$ angle ((a) empty room at 80 bar, (b) loaded rooms at 40 bar nozzle, (c) loaded rooms at 80 bar nozzle); (d) loaded rooms at 80 bar nozzle, $3.4 \mathrm{~m}$ vertical position and $0^{\circ}$ angle; (e) loaded rooms at 80 bar nozzle, $3.25 \mathrm{~m}$ vertical position and $30^{\circ}$ angle; coloured with droplet diameter: $70 \mu \mathrm{m}$ (red), $9 \mu \mathrm{m}$ (blue). 

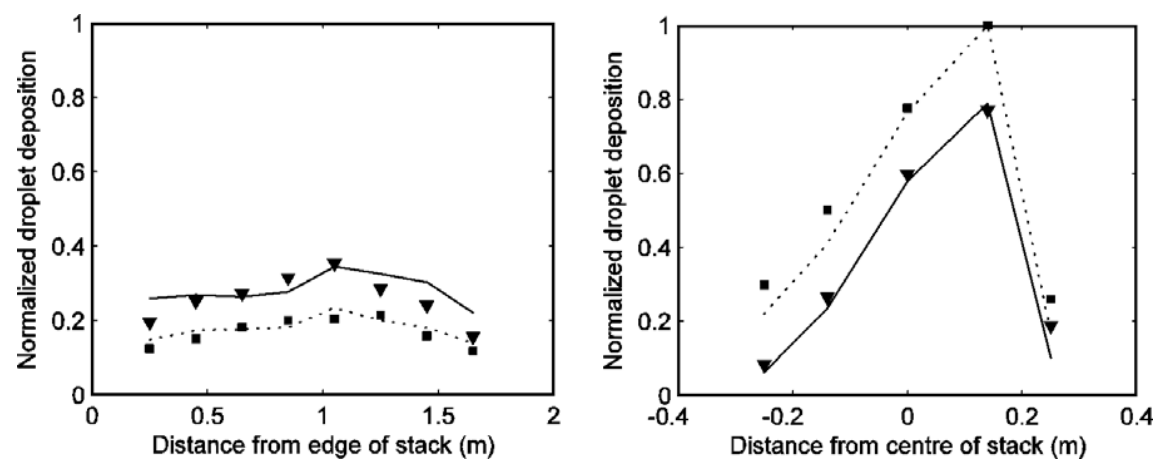

Fig. 12. Amount of sprayed droplet deposit on the floor in front of the stack (left) and top of the stack (right) after $22 \mathrm{hr}$ of interval spraying (1 min on and $15 \mathrm{~min}$ off), for $-1{ }^{\circ} \mathrm{C}$ room temperature: - (predicted with 80 bar pressure); $\mathbf{\nabla}$ (measured with 80 bar pressure); ... (predicted with 40 bar pressure), $\mathbf{\square}$ (measured with 40 bar pressure).
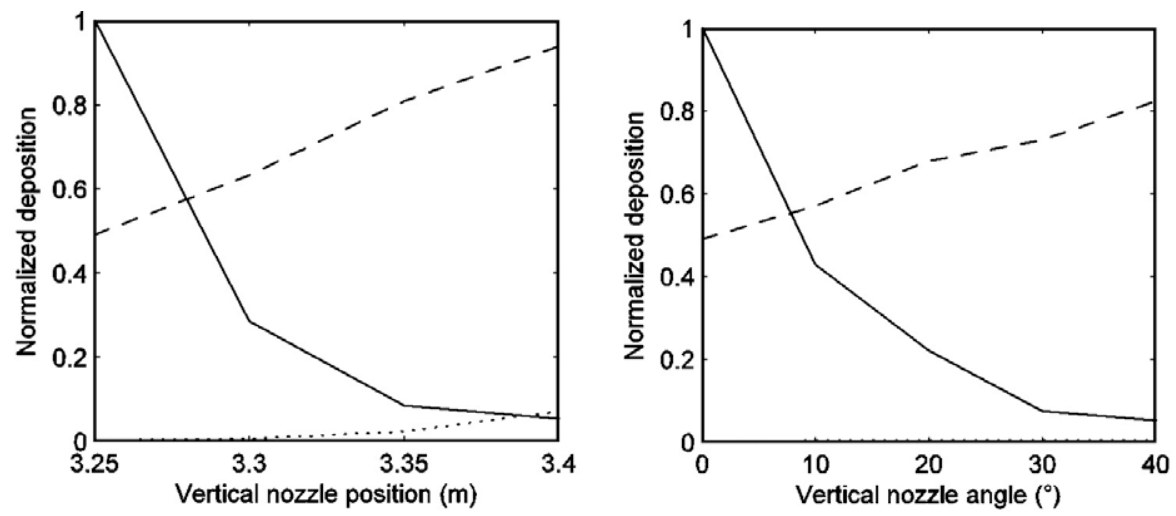

Fig. 13. Predicted droplet deposition on top of the stack, floor in front of the stack and roof of the room at 80 bar nozzle pressure, for different vertical nozzle position (left) and angle (right), for $-1{ }^{\circ} \mathrm{C}$ room temperature: - (top); - (floor); ... (roof).

While without humidification the equilibrium $\mathrm{RH}$ was $93.8 \%$, humidification brought the average $\mathrm{RH}$ to a level of $96.3 \%$. The weight loss rate was decreased from $1.02 \% /$ month to $0.61 \% /$ month by including the humidification. This is in the same range with the result that was reported by Nguyen et al. (2007); for the same storage temperature and $\mathrm{RH}$ of $95 \%$ and $97 \%$ over storage time of 9 months a weight loss of 5.6 and $3 \%$ was observed, respectively. The peaks of the predicted result were sharper than the measured results; this could be due to the response time of the sensors ( $2 \mathrm{~min}$ ). The model over predicted the peak $\mathrm{RH}$ but produced the correct trends and dynamics of the system.

\subsection{Optimization of nozzle operation}

While we demonstrated in the previous sections the positive effects on cooling rate and product weight loss, the nozzle operation must be carefully designed to avoid excessive misting, leading to condensation and insufficient evaporation of water droplets. The tracks of the sprayed droplets for empty and loaded rooms are given in Fig. 11. Most of the droplets were carried by the high velocity cold air that was coming out of the cooler. Part of the droplets that were not completely evaporated entered the cooler. The loading of the room affected both the velocity of the air jet and the dispersion of the sprayed droplets. Some of the larger droplets had a tendency to escape from the confined air jet region at the ceiling and dropped down on the stack (Fig. 11b and c). The dispersion of the droplets was affected by nozzle position and direction and water pressure.

The amount of water deposited on the top of the stack and floor in front of the stack at 40 and 80 bar nozzle pressure is given in Fig. 12. The amounts deposited on the other locations (sides of the stack, inside the stack and floor other than the front side of the stack) were relatively very small. The plotted values are values normalized with the maximum observed deposition. The highest deposition of the sprayed droplet was observed on the top of the stack followed by the deposition on the floor in front of the stack. Decreasing the application pressure increased the deposition on top of the stack and the inverse effect was seen on the floor (Figs. $11 \mathrm{~b}, \mathrm{c}$ and 12). This was due to the increase in droplet size with a decrease in water pressure (Table 1). There was good agreement between measured and predicted results. The overall average relative error was found to be only $15.9 \%$.

Increasing the vertical position and angle of nozzle decreased the deposition on the top of the stack, while the floor and roof deposition was increased (Fig. 13). Relative to the maximum deposition observed, the percentage decrease of the deposition on the top of the stack was higher than the percentage increase on the floor and roof combined. By increasing the vertical nozzle position and angle from 3.25 to $3.35 \mathrm{~m}$ and 0 to $30^{\circ}$, there was a $91.6 \%$ and $92.5 \%$ decrease of top deposition, respectively. Similarly, there was 31.7 and $23.8 \%$ increase in floor plus roof deposition, respectively. The increase in floor and roof deposition due to the increase of the vertical angle of the nozzle was smaller than the increase due to the increase in vertical position. Increasing the vertical angle of the nozzle increased the tendency of the coarser droplets to stay within the high velocity confined air jet (Fig. 11e); this increased the rate of evaporation.

\section{Conclusion}

A complete CFD model of a cool room, including product characteristics, stacking pattern, evaporator dynamics and humidification compared well with measured distributions of velocity, 
temperature, humidity and droplet deposition inside the cold storage room with an installed humidification system. $1 \mathrm{~min}$ on and 10 min off interval humidification during cooling allowed increasing $\mathrm{RH}$ with $10.1 \%$ on average, reducing the cooling time with $15.8 \%$ and reducing the weight loss with $1.13 \%$; $1 \mathrm{~min}$ on and 15 min off interval humidification during storage at $-1{ }^{\circ} \mathrm{C}$ raised the $\mathrm{RH}$ with $2.5 \%$ and decreased the weight loss by $40.2 \%$. The result demonstrated clearly the applicability of CFD models to study the effects of different operating parameters on the efficiency of the humidification system and to identify the optimum operating condition of the system that produce the maximum evaporation and minimum deposition of the sprayed water droplets.

\section{Acknowledgement}

The Interfaculty Council for Development Co-operation (IRO) and IWT project 060720 are gratefully acknowledged for financial support. Pieter Verboven is Fellow of the Industrial Research Fund of the K.U. Leuven. In addition, we like to acknowledge the Université Libre de Bruxelles (Prof. Dr. Karim AMIGHI) for use of the Malvern Spraytec unit.

\section{References}

Anonymous, 2006. FLUENT 6.3 User's Guide. Fluent, Inc., Lebanon, NH, USA.

Antohe, B.V., Lage, J.L., 1997. A general two-equation macroscopic turbulence model for incompressible flow in porous media. International Journal of Heat and Mass Transfer 40 (13), 3013-3024.

Alvarez, G., Flick, D., 1999. Analysis of heterogeneous cooling of agricultural products inside bines. Part I: Aerodynamic study. Journal of Food Engineering 39, 227-237.

Alvarez, G., Bournet, P-E., Flick, D., 2003. Two-dimensional simulation of turbulent flow and transfer through stacked spheres. International Journal of Heat and Mass Transfer 46, 2459-2469.

Bayvel, L., Orzechowski, Z., 1993. Liquid Atomization. Taylor \& Francis, Washington, DC, USA.

Bertola, V., Cafaro, E., 2006. Thermal instability of viscoelastic fluids in horizontal porous layers as initial value problem. International Journal of Heat and mass Transfer 49, 4003-4012.

Bird, R.B., Stewart, W.E., Lightfoot, E.N., 2002. Transport Phenomena, second ed. John wiley \& Sons, Inc., New York, USA.

Carson, J.K., 2006. Review of effective thermal conductivity models for foods. International Journal of Refrigeration 29, 958-967.

Chourasia, M.K., Goswami, T.K., 2007. CFD simulation of effects of operating parameters and product on heat transfer and moisture loss in the stack of bagged potatoes. Journal of Food Engineering 80 (3), 947-960.

Delele, M.A., Tijskens, E., Atalay, T.A., Ho, Q.T., Ramon, H., Nicolaï, B.M., Verboven, P., 2008. Combined discrete element and CFD modeling of airflow through random stacking of horticultural products in vented boxes. Journal of Food Engineering 89 (1), 33-41.

Delele, M.A., Verboven, P., Schenk, A., Ramon, H., Nicolaï, B.M., 2007a. Assessment of humidification using pressurized water atomizers for ULO storage of conference pears. In: Proceedings of the 22nd IIR International Congress of Refrigeration, Beijing, P.R. China.

Delele, M.A., Jaeken, P., Debaer, C., Ramon, H., Nicolaï, B.M., Verboven, P., 2007b. CFD prototyping of an air-assisted orchard sprayer aimed at drift reduction. Computers and Electronics in Agriculture 55, 16-27.

Ergun, S., 1952. Fluid flow through packed columns. Chemical Engineering Progress $48,89-94$.

Forchheimer, P., 1901. Wasserbewegung durch Boden. Zeitschrift des Vereines Deuts Ingenieure 45, 1736-1741.

Ferrua, M.J., Singh, R.P., 2008. A nonintrusive flow measurement technique to validate the simulated laminar fluid flow in a packed container with vented walls. International Journal of Refrigeration 31, 242-255.
Gosman, A.D., Ioannides, E., 1981. Aspects of computer simulation of liquid fuelled combustors. AIAA paper No. 81-0323.

Gouesbet, G., Berlemont, A., 1999. Eulerian and Lagrangian approaches for predicting the behaviour of discrete particles in turbulent flows. Progress in Energy and Combustion Sciences 25, 133-159.

Haider, A., Levenspiel, O., 1989. Drag coefficient and terminal velocity of spherical and nonspherical particles. Powder technology 58,63-70.

Hamdami, N., Monteau, J-Y., Le Bail, A., 2004. Simulation of coupled heat and mass transfer during freezing of a porous humid matrix. International Journal of Refrigeration 27, 595-603.

Henriod, R.E., 2006. Postharvest characteristics of navel oranges following high humidity and low temperature storage and transport. Postharvest Biology and Technology 42, 57-64.

Hertog, M.L.A.T.M., Ben-Arie, R., Róth, E., Nicolaï, B.M., 2004. Humidity and temperature effects on invasive and non-invasive firmness measures. Postharvest Biology and Technology 33, 79-91.

Hoang, M.L., Verboven, P., Baelmans, M., Nicolaï, B.M., 2003. A continuum model for airflow, heat and mass transfer in bulk of chicory roots. Transactions of the ASAE 46 (6), 1603-1611.

Hoang, M.L., Verboven, P., De Baerdemaeker, J., Nicolaï, B.M., 2000. Analysis of air flow in a cold store by means of computational fluid dynamics. International Journal of Refrigeration 23, 127-140.

Laguerre, O., Ben Amara, S., Alvarez, G., Flick, D., 2008. Transient heat transfer by free convection in a packed bed of spheres: comparison between two modelling approaches and experimental results. Applied Thermal Engineering 28, 14-24.

Masuoka, T. Takatsu, Y, 1996. Turbulence model for flow through porous media. International Journal of Heat and Mass Transfer 39 (13), 2803-2809.

Menter, F.R., 1994. Two equation Eddy-viscosity turbulence models for engineering applications. AIAA Journal 32 (8), 1598-1605

Mirade, P-S., Picgirard, L., 2006. Improvement of ventilation homogeneity in an industrial batch-type carcass chiller by CFD investigation. Food Research International 39, 871-881.

Moureh, J., Flick, D., 2004. Airflow pattern and temperature distribution in a typical refrigeration truck configuration loaded with pallets. International Journal of Refrigeration 27, 464-474.

Nakayama, A., Kuwahara, F., 2005. Algebraic model for thermal dispersion heat flux within porous media. AIChE Journal 51 (10), 2859-2864.

Nakayama, A., Kuwahara, F., 1999. A macroscopic turbulence model for flow in a porous medium. Journal of Fluids Engineering - Transactions of the ASME 121, 427-433.

Nahor, H.B., Hoang, M.L., Verboven, P., Baelmans, M., Nicolaï, B.M., 2005. CFD model of the airflow, heat and mass transfer in cooling stores. International Journal of Refrigeration 28, 368-380.

Nguyen, T.A., Verboven, P., Schenk, A., Nicolaï, B.M., 2007. Prediction of water loss from pears (Pyrus communis cv. Conference) during controlled atmosphere storage as affected by relative humidity. Journal of Food Engineering 83, 149155

Paull, R.E., 1999. Effect of temperature and relative humidity on fresh commodity quality. Postharvest Biology and Technology 15, 263-277.

Rajan, R., Pandit, A.B., 2001. Correlations to predict droplet size in ultrasonic atomisation. Ultrasonics 39, 235-255.

Ranz, W.E., Marshall, W.R., 1952a. Evaporation from drops: Part I. Chemical Engineering Progress 48, 141-146.

Ranz, W.E., Marshall, W.R., 1952b. Evaporation from drops: Part II. Chemical Engineering Progress 48, 173-180.

Tassou, S.A., Xiang, W., 1998. Modelling the environment within a wet air-cooled vegetable store. Journal of Food Engineering 38, 169-187.

Tso, C.P., Cheng, Y.C., Lai, A.C.K., 2006. An improved model for predicting performance of finned tube heat exchanger under frosting condition, with frost thickness variation along fin. Applied Thermal Engineering 26, 111-120.

Tu, K., Nicolaï, B., De Baerdemaeker, J., 2000. Effect of relative humidity on Apple quality under simulated shelf temperature storage. Scientia Horticulturae 85, 217-229.

Verboven, P., Flick, D., Nicolaï, B.M., Alvarez, G., 2006. Modelling transport phenomena in refrigerated food bulks, packages and stacks: basics and advances. International Journal of Refrigeration 29, 985-997.

Versteeg, H.K., Malalasekera, W., 1995. An introduction to Computational Fluid Dynamics-The Finite Volume Method. John Wiley and sons, New York, USA.

Wilcox, D.C., 2000. Turbulence Modeling for CFD, second ed. DCW Industries, Inc., La Canada, California, USA

$\mathrm{Xu}$, Y., Burfoot, D., 1999. Simulating the bulk storage of food stuffs. Journal of Food Engineering 39, 23-29. 